Uluslararası Sosyal Bilgilerde Yeni Yaklaşımlar Dergisi, 2021, 5(1), 191-215

International Journal of New Approaches in Social Studies, 2021, 5(1), 191-215

\title{
Okul Öncesinde Sosyal Bilgiler Eğitimine İlişkin Öğretmen Görüşlerinin İncelenmesi
}

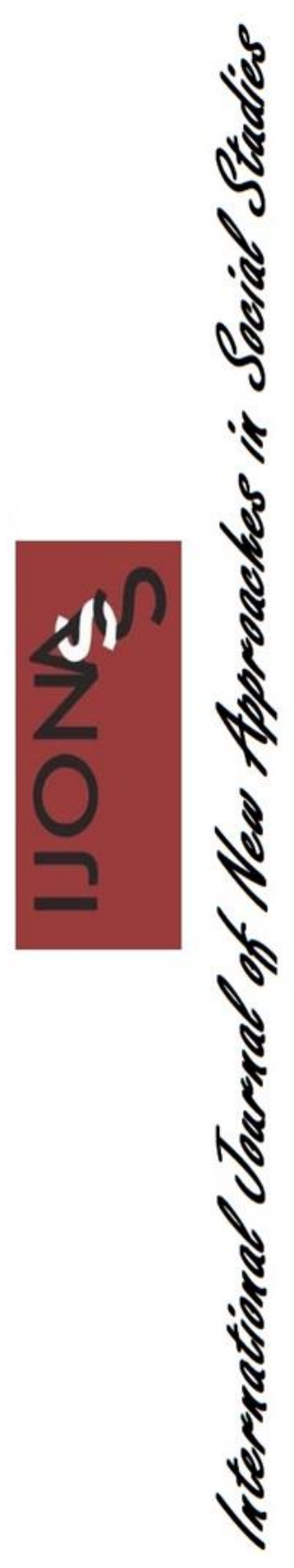

\author{
Demet ÖNER ${ }^{1 *}$ (1) \& E. Özlem YİĞIT ${ }^{2}$ (D)
}

Gönderilme Tarihi: 10 Nisan 2021

Kabul Tarihi: 31 Mayı 2021

DOI: $10.38015 /$ sbyy. 913056

\begin{abstract}
Öz:
Türkiye'de sosyal bilgiler, ilkokul ve ortaokul kademelerinde zorunlu ders olarak verilmektedir. Ancak bireyin sosyal bilgilere ihtiyacı yalnızca belli eğitim dönemleri ile sinırlandırllamayacak kadar önemlidir çünkü bireyin sosyal bilgilere ihtiyacı kendisini tanıma ve çevresini anlamlandırma ihtiyacı ile başlayarak yaşam boyu devam eden bir süreçtir. Sosyal bilgilere ihtiyacın en fazla olduğu eğitim kademelerinden birisi de okul öncesi eğitimdir. Bu nedenle araştırmanın amacı okul öncesi ögretmenlerinin sosyal bilgilere ilişkin görüşlerini tespit etmektir. Araştırmada nitel araştırma yaklaşımlarından temel nitel araştırma kullanılmıştır. Araştırmanın verileri 2017-2018

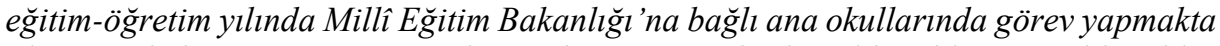
olan 40 okul öncesi ögretmeni ile yapllan görüşmelerden elde edilmiştir. Elde edilen veriler ise nitel veri analiz tekniklerinden betimsel analiz ile çözümlenmiştir. Araştırma sonucunda, okul öncesi öğretmenlerinin sosyal bilgiler algılarının önemli bir kısmını Tarih Öğretimi, Coğrafya Öğretimi ve Vatandaşlık Bilgisi'nin oluşturduğu; geçmiş ögrenim yaşantılarında sosyal bilgiler dersine karşı görüşlerinin olumlu yönde yüksek olduğu tespit edilmiştir. Tüm katılımcıların (n:40) okul öncesi eğitimde sosyal bilgilerin gerekli olduğunu ve bu doğrultuda okul öncesi eğitimde sosyal bilgilerin yer alması gerektiğini düşündükleri, ayrıca okul öncesi öğretmenlerinin sosyal bilgiler kapsamında en fazla gerçekleştirdikleri etkinliklerin başında Coğrafya etkinliklerinin geldiği belirlenmiştir.
\end{abstract}

Anahtar Kelimeler: Okul öncesi, sosyal bilgiler eğitimi, okul öncesi eğitimi, öğretmen görüşleri.

\begin{abstract}
:
Social studies in Turkey, is given as a compulsory subject in primary and secondary school levels. However, the individual's need for social information is so important that it can not be limited to only certain educational periods, because the individual's need for social knowledge is a lifelong process, starting with the need to recognize himself and to make sense of his environment. One of the education levels that need the most social information is preschool education. For this reason, the purpose of the research is to determine the opinions and in-class practices of preschool teachers regarding social information. Basic qualitative research has been used in qualitative research approaches in research. The data from the study were obtained from interviews with 40 preschool teachers who were working in the main schools attached to the Ministry of National Education in the academic year of 2017-2018. The obtained data were analyzed by descriptive analysis from qualitative data analysis techniques. As a result of the research, it is found that a significant part of the pre-school teachers' perceptions
\end{abstract}

\footnotetext{
${ }^{1}$ Abant İzzet Baysal Üniversitesi, Türkiye, ORCID ID: 0000-0002-0186-9838

${ }^{2}$ Abant İzzet Baysal Üniversitesi, Türkiye, ORCID ID: 0000-0002-3362-3437

*SorumluYazar (Corresponding Author): onerr.demet@gmail.com
} 
of social information are composed of History Teaching, Geography Teaching and Citizenship Information; it has been determined that attitudes towards social studies lessons in past education experiences are higher in positive direction. It has been determined that all participants ( $n: 40)$ think that social information is necessary in preschool education and that social information should be included in pre-school education in this direction, and Geography activities are the most important activities that pre-school teachers perform in social information.

Keywords: Pre-school, Social Studies Education, Pre-School Education, Teacher's Opinions

\section{GíRiş}

Okul öncesi eğitimi ülkemizde yeni bir öğretim kademesi olmamakla birlikte, zorunlu eğitim kapsamında yer almaması nedeniyle yeterli düzeyde gelişme gösterememiştir. Nitekim Türkiye'de 1908 yılında bazı illerde rastlanan okul öncesi eğitim kurumları 1912-1913 yıllarında ilk kez resmi olarak kurulmasına rağmen ancak 1960'lardan sonra gelişme gösterebilmiştir (Çelik \& Gündoğdu, 2007). Cumhuriyetin ilan edildiği 1923 yılında 80 anaokulu, 136 öğretmen ve 5.880 öğrenci varken (Taner-Derman \& Başal, 2010); bu sayı 2020 y1lında 1.629.720 öğrenci, 56.218 öğretmen ve 11.485 okul öncesi eğitim kuruma ulaşmıştır (MEB, 2017). Bu artışlara rağmen okul öncesi eğitimde arzu edilen düzeye ulaşılamaması, devletin bu kapsamdaki politikasında bazı değişiklikleri gerektirmiştir. Bu bağlamda 20142018 Onuncu Kalkınma Planı'nda (Kalkınma Bakanlığı, 2013), 2017-2019 Orta Vadeli Program'da (Kalkınma Bakanlığı, 2016) ve 2015-2019 yıllarını kapsayan Millî Eğitim Bakanlığı Stratejik Planı'nda (MEB, 2015) okul öncesi eğitim ile ilgili hedeflerde, tüm çocukların en azından bir yıl okul öncesi eğitim alarak ilkokula başlamasını sağlamak ve bu doğrultuda okullaşma oranını artırmak için kademeli olarak zorunlu okul öncesi eğitime geçilmesine öncelik vermiştir.

2017-2018 eğitim-öğretim yılında, belirlenen pilot illerde zorunlu okul öncesi eğitim programı uygulanmaya başlanmıştır. Yakın bir tarihte ise okul öncesi eğitimin zorunlu hale getirilmesi planlanmaktadır. Tüm bu gelişmelerden hareketle okul öncesi eğitim programlarının zorunlu eğitimde kullanılan öğretim programları ile uyumlu hale getirilmesi gerekmektedir. Söz konusu öğretim programlarından biri ise sosyal bilgiler dersine aittir. Okul öncesi eğitim programlarının ilkokul hayat bilgisi ve sosyal bilgisi derslerine temel oluşturmasını sağlamak ve bu doğrultuda yapılacak değişikliklere zemin hazırlamak için çalışmada okul öncesi eğitim programında sosyal bilgilerin mevcut durumu ve önemi ortaya koyulmaya çalış1lmıştır.

Alanyazın incelendiğinde okul öncesi eğitimde sosyal bilgilere yönelik akademik çalışmaların yetersiz olduğu görülmüştür. Yükseköğretim Kurulu Başkanlığı'nın (YÖK) Ulusal Tez Merkezi'nde de okul öncesi eğitimde sosyal bilgilere yönelik lisansüstü tezlere rastlanılmamıştır. Türkiye'de okul öncesi eğitimde sosyal bilgilere ilişkin çalışmalara ve öğretim programında sosyal bilgilere yer verilmezken öte yandan Amerika Birleşik Devletleri gibi bazı ülkelerde okul öncesi eğitim programlarında sosyal bilgilere yer verilmektedir (Akhan \& Şimşek-Çetin, 2015). Dolayısıyla bu araştırma ile Türkiye'nin eğitim alan yazınına katkı sağlayacağı düşünülmektedir.

\section{Okul Öncesinde Sosyal Bilgiler Ĕ̈itimi}

Sosyal bilgiler, kısaca insan ve toplumla ilgili her şey olarak tanımlanabilir. Kısaca yapılan bu tanım detaylandırıldığında çok geniş bir içeriği bünyesinde barındırmaktadır. Böylesine geniş bir içeriğe sahip olan sosyal bilgiler Türkiye'de ilkokul ve ortaokul kademelerinde doğrudan zorunlu bir ders olarak veriliyorken, içeriğini oluşturan birçok disipline ilkokuldan 
yükseköğretime kadar tüm kademelerde yer verilmektedir. Eğitim-öğretim sürecinin her kademesinde önemli bir yere sahip olan bu çalışma alanının okul öncesi eğitimden ayrı olarak düşünülemeyeceği söylenebilir. Okul öncesi dönemdeki çocukların eğitiminde tarih, coğrafya, ekonomi, arkeoloji, antropoloji gibi sosyal bilimlerin yanı sıra bazı vatandaşlık konularına da yer verilmektedir. Mindes (2005) çocukların halihazırda sosyal bilgilerin içinde doğduklarını, doğumdan itibaren sosyal ve fiziksel çevrelerini keşfederek dünyalarını anlamlandırdıklarını ifade etmiştir. Epstein (2014) ise sosyal bilgiler eğitim programının çocukların ufuklarını okulun ötesine, yakın çevresine ve dünyaya doğru genişlettiğini belirtmiştir. Dolayısıyla sosyal bilgileri sadece bir ders gibi düşünmek ve belli eğitim kademleriyle sınırlandırmak yanlış bir yaklaşım olacaktır.

Yaşamda karşıllı̆ı bulunan sosyal bilimler ilkokul ve ortaokul öğrencilerine sosyal bilgiler aracılığıyla verilmektedir. Beşerî ve doğa bilimlerinden geniş bir yelpazedeki içeriği kapsayan sosyal bilgiler, insana ilişkin tüm konuları ele alır (Uçuş-Güldalı, 2017). Toplumsal gelişimin bir uzantısı olarak çeşitli görevleri bulunan sosyal bilgiler günümüz dünyasındaki çocukları sorumlulukları paylaşmaya, bunlara yönelik farkındalığa ve iyi vatandaşlar olmaya zorlamaktadır (Uçuş-Güldalı \& Demirbaş, 2017). Tüm bunlar sosyal bilgilerin etkili vatandaş yetiştirme amacı kapsamında ele alınabilir. Çünkü sosyal bilgiler eğitimi sorgulamaya dayalı süreçleri kullanarak öğrencilerin problem çözme becerilerini geliştirirken aynı zamanda yurttaşlık bilincini de geliştirir (Mindes, 2005). Sosyal bilgiler eğitiminde en etkili kuruluşlardan biri olan National Council fort he Social Studies (NCSS) (2019) sosyal bilgiler öğretiminin erken çocukluk döneminde çocuklara gerçek dünyadaki sorunları belirleme, kapsayıcı ve demokratik bir toplum yaratma gibi birçok konuda desteklediğini ifade etmiştir. Bunlara ek olarak okul öncesi eğitimin amaçlarından birisi de yaptırılacak etkinliklerle öğrencilerin gruplara dâhil olmasını, kültürel değerlere sahip çıkmasını sağlıklı ilişkiler kurmasını ve sosyalleşmesini sağlamaktır (Yıldır, 1991). Kaya ve Öner'in (2017) de belirttiği gibi sosyal bilgiler bireyin sosyalleşmesi amacıyla tasarlanmış bir derstir. $\mathrm{Bu}$ açıdan sosyalleşme hem sosyal bilgilerin hem de okul öncesi eğitimin temel amaçlarından birisi olduğu ifade edilebilir.

Aktın (2014) farklı etnik kökene ve kültüre sahip vatandaşların demokratik bir ortamda bir arada sorumlu ve etkili vatandaşlar olarak yetiştirilmesi için alanyazında yapılan çalışmaların okul öncesinde sosyal bilgiler eğitiminin vatandaşlığa ilişkin temel bilgi, beceri ve tutum kazanımı için temel oluşturduğunu belirtmiştir. Çünkü bir okul öncesi sınıfı daha geniş bir toplumun küçük bir evrenini oluşturmaktadır (Epstein, 2014). Dolayısıyla daha büyük bir evrende yer almadan önce öğrenciler okul öncesi sınıflarında vatandaşlık bilgi ve becerilerini öğrenmekte ve geliştirmektedirler. Okul öncesi dönemde sosyal bilgiler eğitiminin beş amaci vardır. Bunlar: bireysel gelişim, bireyler arası farklılıklara saygı, sosyal gerçekliklere ilişkin bilgi birikimi, sosyal ve medeni yetkiler ile küresel vatandaşlıktır (Uçuş-Güldalı, 2017). Gainsley ve Neill (2018) ise erken çocuklukta sosyal bilgilere ilişkin çeşitlilik, toplumsal roller, karar verme, coğrafya, tarih ve ekoloji olmak üzere 6 anahtar kavramın verilmesi gerektiğini belirtmiştir.

Türkiye'de sosyal bilgiler öğretiminin içeriği ilk olarak ilkokul 1, 2 ve 3. sınıfta yer alan hayat bilgisi dersi ile başlamaktadır. İlkokul 4, ortaokul 5, 6 ve 7. sınıflarda ise sosyal bilgiler adıyla ayrı bir ders olarak verilmektedir. Ancak Aktın (2014) çocukların birinci sınıfa kadar vatandaşlık algısının bir şekilde informal olarak kazandıkları düşünüldüğünde bazı temel vatandaşlık değerlerinin kazandırılması için ilkokul birinci sınıfın geç bir aşama olduğunu ifade etmektedir. Bireyin psikolojik, sosyal gelişimi ve kişilik özelliklerinin temellerinin atıldığ $10-6$ 
yaş arası çocukluk çağının oldukça önemli bir dönem olduğu (Öngider, 2013) dikkate alındığında okul öncesi eğitimde sosyal bilgilerin önemi ortaya çıkmaktadır.

Akhan ve Şimşek-Çetin (2015) okul öncesi eğitimin hedeflerinden birisinin de çocukları ilkokula hazırlamak olduğunu bu bağlamda Okul Öncesi Eğitim Programında sosyal bilgiler eğitimine yönelik herhangi bir etkinlik alanın olmamasını önemli bir eksiklik olarak değerlendirmişlerdir. Seefeldt (2005) de sosyal bilgilerin erken çocukluk dönemindeki çocuklar için geniş bir alan olduğunu, bu dönemdeki çocukların pek fazla bir deneyime sahip olmadıklarından dolayı tarih, coğrafya, ekonomi gibi alanlardaki bilgilerinin ve demokratik bir toplum için gerekli beceri ve tutumlarının yeterli olmadığını ifade etmiş, bu nedenle erken çocukluk döneminde sosyal bilgiler eğitiminin sonraki y1llarda edinilecek bilgilere zemin oluşturması açısından gerekli görmüştür (akt. Akhan \& Şimşek-Çetin, 2015).

Okul öncesi eğitim programının amacı çocuklara temel yaşam becerilerini öğreterek yaşama ve ilkokula hazırlamaktır. Bu nedenle çocukların yeni tanıştığı kişilerle nasıl iletişim kurması gerektiği, topluma nasıl uyum sağlaması gerektiği okul öncesi eğitim programı ile verilmektedir (Uçuş-Güldalı \& Demirbaş, 2017). Okul öncesi eğitim programı incelendiğinde programda sosyal bilgilere veya sosyal bilimlere ilişkin bir etkinlik alanına yer verilmediği görülmektedir. Ancak programda bilişsel ve sosyal duygusal alanda sosyal bilgilere ilişkin kazanımlara yer verildiği ifade edilebilir. Sosyal bilgilere ilişkin bu kazanımlar Tablo 1'de gösterilmiştir.

Tablo 1. 2013 MEB Okul Öncesi Eğitim Programında Sosyal Bilgiler Eğitimine Yönelik Bazı Kazanım Örnekleri (MEB, 2013a)

\section{BİLISSEL ALAN}

Kazanım 10. Mekânda konumla ilgili yönergeleri uygular.

Kazanım 18. Zamanla ilgili kavramları açıklar.

Kazanım 21. Atatürk'ü tanır ve Türk toplumu için önemini açıklar.

\section{SOSYAL DUYGUSAL ALAN}

Kazanım 1. Kendisine ait özellikleri tanıtır.

Kazanım 2. Ailesiyle ilgili özellikleri tanıtır.

Kazanım 6. Kendisinin ve başkalarının haklarını korur.

Kazanım 8. Farklılıklara saygı gösterir.

Kazanım 9. Farklı kültürel özellikleri açıklar.

Kazanım 10. Sorumluluklarını yerine getirir.

Kazanım 11. Atatürk ile ilgili etkinliklerde sorumluluk alır.

Kazanım 12. Değişik ortamlardaki kurallara uyar.

Kazanım 13. Estetik değerleri korur.

Kazanım 14. Sanat eserlerinin değerini fark eder.

Kazanım 16. Toplumsal yaşamda bireylerin farklı rol ve görevleri olduğunu açıklar.

Kazanım 17. Başkalarıyla sorunlarını çözer.

Tablo 1'de yer alan 2013 Millî Eğitim Bakanlığı Okul Öncesi Eğitim Programı'nda yer alan sosyal bilgiler kazanımları incelendiğinde vatandaşlık, coğrafya ve tarih kazanımlarının varlığı dikkat çekmektedir. Ancak gerek programda gerekse de etkinlik programında sosyal bilgilere ilişkin doğrudan bir alana yer verilmemiştir. Kazanımlar dışında okul öncesi eğitim programında sosyal bilgilere yönelik içeriklere belirli gün ve haftalar ile ilgili bölümde de rastlanılmaktadir.

Genel olarak eğitimde özelde ise sosyal bilgiler öğretiminde sıklıkla yararlanılan Belirli Gün ve Haftalar okul öncesi eğitimde de önemli bir yere sahiptir. MEB Okul Öncesi Eğitim Programın'da (2013a) öğretmenlere Dünya Çocuk Günü, Cumhuriyet Bayramı, Atatürk Haftası, Kızılay Haftası, İnsan Hakları ve Demokrasi Haftası, Hayvanları Koruma Günü, Enerji 
Tasarrufu Haftası, Ulusal Egemenlik ve Çocuk Bayramı, Orman Haftası, Trafik ve İlk Yardım Haftası, Kütüphane Haftası, Müzeler Haftası gibi belirli gün ve haftalardan yararlanılmasını önermiştir. Sosyal Bilgiler Dersi Öğretim Programı'nda (SBDÖP, 2018) ise programın uygulanmasında dikkat edilecek hususlar kısmında öğrencilerin tarihsel duyarlılığını ve milli bilinçlerini geliştirilmek için millî ve dinî bayramlar, önemli olaylar ve belirli gün ve haftalardan yararlanılması istenilmiştir.

Sosyal bilgilere Türkiye'de okul öncesi dönemde yer verilmemesine rağmen Amerika Birleşik Devletleri gibi bazı ülkelerde okul öncesi eğitim programında yer almaktadır (Akhan \& ŞimşekÇetin, 2015). Amerika Birleşik Devletleri'nde sosyal bilgiler öğretimine erken çocukluk döneminde, kendi içinde bütünleşmiş alanlar ve disiplinler altında verilmekte, okul öncesi eğitimde sosyal bilgiler eğitim programında küresel eğitim, tarih, coğrafya, ekonomi ve güncel konular olmak üzere beş farklı alan çatısı altında insan grupları ile ilgili içeriklere odaklanılmaktadır (Akhan \& Şimşek-Çetin, 2015; Uçuş-Güldalı \& Demirbaş, 2017). ABD’nin California, Massachusetts ve North Carolina eyaletlerinde sosyal bilgiler programı akademik bir içerik ve anlayışla sorumlu ve demokratik değerlere sahip vatandaşların yetiştirilmesi için tarih, coğrafya, vatandaşlik ve ekonomi gibi farklı disiplinleri ele alan bir anlayışla verilmektedir (Aktın \& Dilek, 2014). Bu disiplinler ortaokul sosyal bilgiler öğretim programının da temel disiplinleridir.

Sosyal bilgiler erken çocukluk eğitimi programında yeni bir içerik alanı olsa da sosyal bilgiler genel olarak oldukça eski bir çalışma alanıdır (Epstein, 2014). Bu bağlamda erken çocukluk eğitim programının merkezinde ve hayati bir parçası olan sosyal bilgiler eğitimi ile çocukların dünyaya karşı daha etkili, verimli ve ahlaki olarak yaklaşmalarının yanı sıra çocukların öğrenmeyi öğrenmesini ve çoklu bakış açılarını değerlendirmelerini de sağlar (Mindes, 2005: 7). Townsend-Butterworth (2014) okul öncesi eğitimin çocuklara ev dişında ilk topluluk duygusunu verdiğini, sosyal bilgiler öğreniminin çocukların arkadaş edinme ve sınıfta karar verme sürecine katılmasıyla başladığını ve sonrasında okulun ötesine geçerek mahalleye ve dünyaya yayılarak devam ettiğini ifade etmiştir. Sosyal bilgiler sosyal bilimleri bünyesinde taşıması nedeniyle bireylere çeşitli yaşam becerileri kazandırmaktadır. Bu yaşam becerilerine ihtiyacın en fazla olduğu dönem olan okul öncesi eğitimde sosyal bilgiler eğitiminden yararlanmak bireyi sağlıklı bir şekilde geleceğe taşıyacaktır.

Bireyin topluma entegrasyonunun gerçekleştirilebilmesi amacıyla çeşitli sosyal ve beşerî bilimlerden seçilen içeriğin öğrencilerin düzeyine indirgenerek bir tema altında verildiği toplu öğretim dersidir. Türkiye'de sosyal bilgiler ilkokul ve ortaokul kademelerinde zorunlu ders olarak verilmektedir. Ancak bireyin sosyal bilgilere ihtiyacı yalnızca belli eğitim dönemleri ile sınırlandırılamayacak kadar önemlidir. Çünkü bireyin sosyal bilgilerin içeriğindeki bilgi, beceri ve değerlere yönelik gereksinimi kendisini tanıma ve çevresini anlamlandırma ihtiyacı ile başlayarak yaşam boyu devam eden bir süreçtir. Sosyal bilgilere ihtiyacın en fazla olduğu kademelerden birisi de okul öncesi eğitimdir. Ancak, alanyazın incelendiğinde (Mindes, 2005; Aktın, 2014; Aktın \& Dilek, 2014; Epstein, 2014; Akhan \& Şimşek-Çetin, 2015; Şimşek-Çetin \& Akhan, 2015; Uçuş-Güldalı, 2017; Uçuş-Güldalı \& Demirbaş, 2017) okul öncesi eğitimde genelde sosyal bilimi, özelde ise sosyal bilgileri ele alan çalışmalar oldukça sınırlıdır. Ayrıca yapılan çalışmalar öğretmen adaylarıyla veya literatür incelemesi üzerine gerçekleştirilmiştir. Bu kapsamda vatandaşlığın ve sosyalleşmenin ilk temellerinin atıldığı okul öncesi eğitimde sosyal bilgilerin öğretmen görüşleriyle tespit edildiği ilk çalışmalardan biri olması açısından bu çalışma önem arz etmektedir. Bu bağlamda araştırmanın amacı okul öncesi öğretmenlerinin sosyal bilgilere ilişkin uygulama ve görüşlerini tespit etmektir. 


\section{YÖNTEM}

\section{Araştırmanın Modeli}

Okul öncesi öğretmenlerinin sosyal bilgilere ilişkin uygulama ve görüşlerini tespit etmeyi amaçlayan bu araştırma nitel araştırma yaklaşımıyla tasarlanmıştır. Glesne'ye (2013) göre ise nitel araştırma kelimeler gibi ölçülmesi zor olan niteliklerin anlamlandırılmasına ve çözümlenmesine dayalı bir araştırma türüdür. Nitel araştırmayı birçok araştırmacı farklı şekillerde sınıflandırmaya çalışmıştır (Denzil \& Lincoln, 2005; Lichtman, 2013, Creswell, 2015). Bu araştırmada Merriam'ın (2013) nitel araştırma sınıflandırmalarından biri olan temel nitel araştırma kullanılmıştır. Merriam'a (2013) göre temel nitel araştırmanın öncelikli amacı insanların hayatlarını ve dünyalarını nasıl anlamlandırdıklarını açığa çıkarmak ve yorumlamaktır. Bu doğrultuda araştırmada okul öncesi öğretmenlerinin mevcut düşünceleri, deneyimleri ve uygulamaları ortaya çıkarılmak istenildiğinden temel nitel araştırma yönteminden yararlanılmıştır.

\section{Çalışma Grubu}

Araştırmanın çalışma grubunun belirlenmesinde "amaçlı örnekleme" yöntemlerinden biri olan 'uygun/elverişli/kolay ulaş1labilir durum örneklemesi' tekniği kullanılmıştır. Kolay ulaşılabilir durum örneklemesi bilimsel araştırmalarda tercih edilmemesi gereken bir teknik olarak ifade edilmektedir (Arslanoğlu, 2016; Balc1, 2016). Ancak bu araştırmada böyle bir örnekleme türünün alınmasının temel nedeni araştırmada veri toplama aracı olarak görüşmeden yararlanılmasıdır. Görüşme yöntemi sürecinin diğer veri toplama yöntemlerine göre uzun bir zaman gerektirmesi nedeniyle araştırmanın çalışma grubunu Kayseri ili Talas ve Melikgazi ilçelerindeki devlet okullarında ve özel okullarda görev yapmakta olan, araştırmada gönüllü olarak yer alan, 40 okul öncesi öğretmeni oluşturmaktadır. Araştırmanın çalışma grubuna ilişkin bilgiler Tablo 2'de verilmiştir.

Tablo 2. Çalışma Grubuna Ilişkin Genel Bilgiler

\begin{tabular}{|c|c|c|c|c|c|c|c|c|c|}
\hline Kod & Cinsiyet & Yaş & Deneyim & $\begin{array}{l}\text { Okul } \\
\text { Türü }\end{array}$ & Kod & Cinsiyet & Yaş & Deneyim & $\begin{array}{l}\text { Okul } \\
\text { Türü }\end{array}$ \\
\hline Ayla & $\mathrm{K}$ & 35 & 12 & $\mathrm{D}$ & Leman & $\mathrm{K}$ & 34 & 12 & $\mathrm{D}$ \\
\hline Ayşe & $\mathrm{K}$ & 40 & 18 & D & Latif & E & 37 & 11 & D \\
\hline Birgül & $\mathrm{K}$ & 48 & 27 & $\mathrm{D}$ & Melis & $\mathrm{K}$ & 30 & 12 & $\mathrm{D}$ \\
\hline Buse & $\mathrm{K}$ & 24 & 3 & Özel & Merve & $\mathrm{K}$ & 34 & 12 & $\mathrm{D}$ \\
\hline Ceyda & $\mathrm{K}$ & 28 & 5 & $\mathrm{D}$ & Naciye & $\mathrm{K}$ & 35 & 7 & D \\
\hline Ceylan & $\mathrm{K}$ & 25 & 1 & Özel & Neriman & $\mathrm{K}$ & 37 & 12 & D \\
\hline Derya & $\mathrm{K}$ & 22 & 1 & Özel & Nuran & $\mathrm{K}$ & 31 & 6 & D \\
\hline Duru & K & 30 & 9 & $\mathrm{D}$ & Oya & $\mathrm{K}$ & 44 & 12 & D \\
\hline Elif & $\mathrm{K}$ & 33 & 9 & D & Olcay & K & 42 & 9 & $\mathrm{D}$ \\
\hline Esra & $\mathrm{K}$ & 28 & 7 & D & Ömür & K & 37 & 13 & $\mathrm{D}$ \\
\hline Fadime & $\mathrm{K}$ & 40 & 17 & D & Özge & K & 38 & 13 & $\mathrm{D}$ \\
\hline Gamze & $\mathrm{K}$ & 33 & 9 & D & Pakize & $\mathrm{K}$ & 39 & 17 & $\mathrm{D}$ \\
\hline Gülizar & $\mathrm{K}$ & 33 & 11 & D & Peri & $\mathrm{K}$ & 42 & 15 & $\mathrm{D}$ \\
\hline Hasibe & $\mathrm{K}$ & 43 & 22 & D & Pinar & $\mathrm{K}$ & 37 & 15 & $\mathrm{D}$ \\
\hline Hayriye & $\mathrm{K}$ & 27 & 5 & D & Raziye & $\mathrm{K}$ & 30 & 7 & $\mathrm{D}$ \\
\hline İpek & $\mathrm{K}$ & 39 & 16 & D & Remziye & $\mathrm{K}$ & 37 & 16 & $\mathrm{D}$ \\
\hline İrem & $\mathrm{K}$ & 50 & 25 & D & Selin & K & 28 & 6 & $\mathrm{D}$ \\
\hline Jale & $\mathrm{K}$ & 34 & 8 & D & Sema & K & 33 & 10 & $\mathrm{D}$ \\
\hline Julide & $\mathrm{K}$ & 37 & 17 & D & Şule & K & 27 & 5 & D \\
\hline Keriman & $\mathrm{K}$ & 31 & 13 & D & Zeynep & $\mathrm{K}$ & 35 & 14 & $\mathrm{D}$ \\
\hline
\end{tabular}

Tablo 2'de çalışma grubunda yer alan katılımcılara ait açıklayıcı bazı bilgilere yer verilmiştir. Araştırmada yer alan katılımcıların 37'si devlet okullarında görev yaparken 3'ü özel okullarda 
görev yapmaktadır. Tablo 2'de görüldügüü üzere, araştırmanın bulgular kısmında katılımcılara ait doğrudan alıntılara yer verilirken kullanılmak üzere her bir katılımcıya rumuz verilerek kodlanmıştır. Katılımcıların mesleki deneyim ortalaması 11,5 yıldır. Araştırmanın çalışma grubunda yer alan 40 katılımcının 39'u Kadın yalnızca 1'i Erkek'tir. Araştırmada cinsiyet dağılımının orantısız olma durumu Eğitim-Bir-Sen'in 2016 yılında hazırladığı Eğitime Bakış 2016 İzleme ve Değerlendirme Raporu verilerine göre kadın öğretmen oranları eğitim kademesi yükseldikçe azalmaktadır. 2015 yılında okul öncesinde kadın öğretmen oranı \%95 civarındadır.

\section{Veri Toplama Aracı ve Yöntemi}

Araştırmanın verilerinin elde edilmesi sürecinde veri toplama aracı olarak yarı yapılandırılmış görüşme formundan yararlanılmıştır. Bu form araştırmacı tarafından geliştirilmiştir. İlgili alanyazın incelendikten sonra okul öncesi öğretmenlerinin sosyal bilgilere ilişkin algı ve uygulamalarını tespit etmek amacıyla 14 sorudan oluşan bir taslak form hazırlanmıştır. Görüşme formunda yer alan sorular Bolu Abant İzzet Baysal Üniversitesi ve Erciyes Üniversitesi'nden birer sosyal bilgiler eğitimi uzmanı, Bolu Abant İzzet Baysal Üniversitesi ve Kırşehir Ahi Evran Üniversitesi'nden yine birer okul öncesi eğitimi uzmanının incelemesine sunulmuştur. Uzman görüşleri neticesinde soru sayısı azaltılmış ve bazı sorularda değişiklikler yapılmıştır. Hazırlanan görüşme formunun pilot uygulaması ise dört okul öncesi öğretmeniyle gerçekleştirilmiştir. Pilot uygulamalar sonrasında görüşme formunda yer alan soruların bazılarının tam olarak anlaşılmadığı bazılarının ise işlevinin yetersiz olduğu tespit edilmiş ve bu maddelerden bazıları düzeltilmiş bazıları ise çıkarılmıştır. Uzman görüşleri ve pilot uygulamalar neticesinde 11 açık uçlu sorudan oluşan yarı yapılandırılmış bir görüşme formu hazırlanmıştır. Görüş formuna son şeklinin verilmesinin ve yasal izin süreçlerinin tamamlanmasının ardından veri toplama sürecine başlanılmıştır.

\section{Verilerin Toplanmast}

Araştırmanın verileri 2017-2018 eğitim-öğretim yılında Kayseri ili merkez Melikgazi ve Talas ilçelerindeki Millî Eğitim Bakanlığı'na bağlı devlet ve özel anaokullarında görev yapmakta olan okul öncesi öğretmenleriyle yapılan görüşmelerden elde edilmiştir. Marshall ve Rossman (1994) gözlem ve görüşmeyi nitel araştırmalarda öncelikli veri toplama teknikleri olarak belirtmektedir (Akt. Balc1, 2016). Büyüköztürk ve diğ. (2015) göre görüşme belirli bir araştırma konusu hakkında derinlemesine bilgi edinilmesini sağlamaktadır. Araştırmanın veri toplama süreci sırayla Sosyal Bilimlerde İnsan Araştırmaları Etik Kurulu'ndan onay raporunun alınması; Kayseri İl Milli Eğitim Müdürlüğ̈̈'nden araştırma izinlerinin alınması; gönüllü katılımcılarla görüşmeler için randevular alınması ve görüşmeler ses kaydı altına alınarak gerçekleştirilmesi şeklinde yürütülmüştür.

\section{Verilerin Analizi}

Nitel araştırmada veri analiz süreci, analiz için verilerin hazırlanmasını ve organizasyonunu, verilerin kodlanmasını ve kodların bir araya getirmesiyle temalara ulaşılmasını ve son olarak verinin şekiller, tablolar veya bir tartışma halinde sunulmasını içermektedir (Creswell, 2015). Nitel araştırmada verilerin analizinde en sık uygulanan teknikler ise; betimsel analiz, içerik analizi ve söylem analizidir (Balc1, 2016). Bu araştırmada ise elde edilen veriler betimsel analiz tekniği ile çözümlenmiştir. Betimsel analizde amaç, elde edilen bulguların düzenli bir şekilde yorumlanarak okuyuculara sunmaktır (Yıldırım ve Şimşek, 2011). Araştırma kapsamında toplanan verilerdeki örüntülerden elde edilen kodlar daha öncesinde alanyazın incelemesi sonucunda belirlenmiş temalara yerleștirilerek frekans ve yüzde değerleri ile birlikte tablolarda verilmiştir. Tabloların hemen altında ise bulgular doğrudan alıntılarla desteklenmiştir. 


\section{Geçerlik ve Güvenirlik Çalışmaları}

Nitel araştırmalarda geçerlilik aktarılabilirlik, güvenirlik ise genellenebilirlik olarak ifade edilebilmektedir. Karasar'a (2015) göre geçerlik, ölçülmek istenen şeyin başka şeylerle karıştırılmadan ölçülebilmesidir. İki tür geçerlik vardır. Bunlar iç geçerlik ve dış geçerliktir. Dış geçerlik, elde edilen sonuçların benzer gruplara ya da ortamlara aktarılabilirliğine, iç geçerlilik ise araştırma sonuçlarına ulaşırken izlenen sürecin çalışılan gerçekliği ortaya çıkarmadaki yeterliliğine ilişkindir. Bu araştırmada geçerlik araştırma sonuçlarının ayrıntılı olarak rapor edilmesi, araştırma sürecinde üç alan uzmanından görüş alınması ve bulguların katılımcı görüşlerinden alınan doğrudan alıntılarla desteklenmesi ile sağlanmaya çalışılmıştır.

Güvenirlik ise en kısa tanımıyla araştırma sonuçlarının tekrar edilebilirliği ile ilgilidir (Yıldırım ve Şimşek, 2011). Görüşmelerden elde edilen bulgular kodlara ayrılarak ilgili temalara yerleştirilmiştir. $\mathrm{Bu}$ aşamada hem araştırmacı hem de bir alan uzmanının görüşlerine başvurularak Miles ve Huberman'ın (1994) önerdiği güvenirlilik formülü uygulanmıştır.

$$
\text { Güvenirlik }=\frac{\text { Görüş Birliğı Sayısı }}{\text { Toplam Görüş Birliği }+ \text { Görüş Ayrılığı }}
$$

Yukarıdaki formülün hesaplaması sonucunda araştırmanın güvenirliği \%86 olarak hesaplanmıştır. Miles ve Huberman'a (1994) göre güvenirlik hesaplarının \%70'in üzerinde çıkması, araştırma için güvenilir kabul edilmektedir. Bu sonuç, araştırma için güvenilir kabul edilmiştir.

Tekrar edilebilirliğin nitel araştırmaların doğasına uygun olmaması nedeniyle araştırmada diş güvenirlik çalışmasına yer verilmemiştir. LeCompte ve Goetz (1982) iç güvenirlik konusunda birtakım stratejiler önermişlerdir. Bu stratejilerden biri de toplanan verilerin betimsel bir yaklaşımla doğrudan sunulmasıdır (akt. Yıldırım ve Şimşek, 2011). Bu bağlamda araştırmada iç güvenirliği sağlamak amacıyla elde edilen veriler betimsel bir yaklaşımla çözümlenmiş ve herhangi bir yoruma yer verilmeden tablolar halinde verilmiştir. Yorumlar ise tablolar altında verilen doğrudan alıntılardan sonrasına bırakılmıştır.

\section{BULGULAR}

Araştırmanın bu bölümünde katılımcılarla yapılan görüşmelerin analiz edilmesiyle ortaya çıkan bulgulara yer verilmiştir. Bulgular; araştırma problemlerine göre sıralı, frekans ve yüzde değerlerini belirten tablolar halinde ve doğrudan alıntılar ile desteklenmiş bir şekilde verilmiştir.

\section{Katılımcıların Sosyal Bilgiler Dersine İlişkin Görüşlerine Yönelik Bulgular}

Katılımcıların sosyal bilgiler dersine ilişkin görüşleri farklı sorulardan elde edilen bulgularla Tablo 3, 4 ve 5'te yer verilmiştir. Okul öncesi öğretmenlerinin sosyal bilgiler dersine ilişkin yaptıkları tanımlamalardan elde edilen bulgular Tablo 3'te verilmiştir. 
Tablo 3. Öğretmenlerin Sosyal Bilgiler Tanımlarına İlişkin Bulgular

\begin{tabular}{lcc}
\hline Tema 1. Öğretmenlerin Sosyal Bilgiler Tanımları & f & \% \\
\hline 1. Birey ve toplumla ilgili her şey & 13 & 25 \\
2. Tarih öğretimi & 11 & 21 \\
3. Coğrafya öğretimi & 9 & 18 \\
3. Öğrencileri toplumsal hayata hazırlayan ders & 9 & 18 \\
4. Yaşam becerisi kazandıran ders & 5 & 10 \\
5. Bireyin çevresini tanıması & 2 & 5 \\
6. Bireyin aktif olması & 1 & 4 \\
7. Kültür aktarımı & 1 & 4 \\
\hline Toplam & $\mathbf{5 1}$ & $\mathbf{1 0 0}$ \\
\hline
\end{tabular}

Tablo 3'e göre katılımcıların \%25'i "birey ve toplumla ilgili her şey”, \%21'i “tarih öğretimi”, \%18'si “coğrafya öğretimi”, \%18'i “öğrencileri toplumsal hayata hazırlayan ders”, \%10'u ise "yaşam becerisi kazandıran ders" olarak yanıt vermişlerdir.

Sosyal bilgileri birey ve toplumla ilgili şeyler olarak ifade eden katılımcılardan bazıları görüşlerini; "Toplum bilimi demektir. Bence bununla eş değer gibi geliyor bana. İnsanın geçmişine ve geleceğine dair yön vermesini, kendini, toprağını, sosyolojik yapısını tanımasını sağlayan bir bilimdir..." (Oya); "toplumu ilgilendiren her şeydir." (Şule) şeklinde açıklamışlardır. Sosyal bilgileri tanımlarken toplumsallaşma/sosyalleşme sürecini temel alarak görüşlerini ifade eden katılımcılardan bazıları "öğrencileri toplumsal hayata hazırlayan ve onlarl sosyal yönden destekleyen ve zorunlu ĕgitim çă̆ında uygulanan bir derstir." (Neriman); "çocukların kendi aralarında iletişim becerileri, akranlarıyla iletişim becerileri ve toplumla daha iyi uyum sağlayabilmesi için kazandiğı becerilerdir" (Gamze) şeklinde görüşlerini ifade etmişlerdir.

Tablo 3'ten hareketle okul öncesi öğretmenlerinin mevcut sosyal bilgiler algılarının ağırlıklı olarak vatandaşlık bilgisine, tarih ve coğrafya öğretimine yönelik olduğu görülmektedir. Sosyal bilgilerin geleneksel içeriğini oluşturan tarih, coğrafya ve vatandaşlık bilgisi konuları 2005 ve 2018 Sosyal Bilgiler Öğretim Programlarında ağırlık oranlarını korumakla birlikte, 2005 öncesi öğretim programlarında ise bu üç temel disiplin daha ön planda yer almıştır. Katılımcıların yaş ortalamasının 34.6 olduğu dikkate alındığında öğretmenlerin önemli bir kısmının üç temel disiplinin yer aldığı 2005 öncesi öğretim programlarından mezun olması bu durumu açıklamaktadır.

Tablo 4. Öğretmenlerin Sosyal Bilgiler Dersine Karşı Tutumlarına Yönelik Bulgular

\begin{tabular}{|c|c|c|}
\hline Tema 2. Öğretmenlerin Sosyal Bilgiler Tutumları & f & $\%$ \\
\hline Olumlu & 31 & 78 \\
\hline 1. Dersin içeriğine ilgi duyduğu için & 25 & 59 \\
\hline 2. Dersin öğretmenini sevdiği için & 4 & 10 \\
\hline 3. Sosyal bir kişiliğe sahip olduğu için & 2 & 5 \\
\hline 4. Ailesinde sosyal bilgiler öğretmeni olduğu için & 1 & 2 \\
\hline Olumsuz & 9 & 12 \\
\hline 5. Dersin içeriği sıkıcı olduğu için & 4 & 10 \\
\hline 6. Dersin öğretmeninden kaynaklı & 3 & 7 \\
\hline 7. Derse karşı bir ilgisi olmadığ 1 için & 2 & 5 \\
\hline 8. Ezbere dayalı bir ders olduğu için & 1 & 2 \\
\hline Toplam & 40 & 100 \\
\hline
\end{tabular}

Tablo 4’te görüldüğü gibi, "Daha önceki öğrenim hayatınızda sosyal bilgiler dersine karş1 tutumunuz nasildı? Neden?" sorusuna 40 katılımcinın 31'i (\%76) olumlu, 9'u (\%24) ise 
olumsuz yönde yanıt vermişlerdir. Öğretmenlerin \%59'u "dersin içeriğine ilgi duyduğu için" sosyal bilgiler dersini sevdiklerini ifade etmişlerdir. Olumsuz tutuma sahip olma nedenlerinin başında ise \%10 ile "dersin içeriği sıkıcı olduğu için" yanıtı gelmektedir.

Sosyal bilgilere yönelik olumlu tutuma sahip olan katılımcılar bu görüşlerini şu şekilde açıklamışlardır: "severdim yani günlük hayat aklşılla ilgili şeyler öğretildiği için severdim. Dersin içeriğini seviyorum" (Özge); Olcay ise "çok seviyordum. Tarihi özellikle çok seviyordum. Inkılap tarihini çok seviyordum. Coğrafyayı da aynı şekilde severdim. Topraklarımızda neler olmuş öğrenmek benim çok hoşuma gidiyordu." demiştir. Sosyal bilgilere yönelik olumsuz tutuma sahip olan katılımcılar ise bunun nedenlerini şu şekilde ifade etmişlerdir: Selin "Hiçbir zaman iyi olmadl. Coğrafyayı severdim ama tarihi hiç sevmedim. Aslında tarih dersinin anlatılış şekli de önemli. ... çok şanslı değildim bu konuda" diyerek sahip olduğu olumsuz tutumun öğretmenden kaynaklandığını ifade etmiştir. Öğretmen görüşleri incelendiğinde öğretmenlerin önemli bir kısmının sosyal bilgiler dersini sevdiği ve derse yönelik tutumlarının olumlu olduğu anlaşılmaktadır.

Tablo 5. Sosyal Bilgiler Dersinin İçeriğine Yönelik Bulgular

\begin{tabular}{lcc|lcc}
\hline Tema 2. Sosyal Bilgiler İçeriği & f & \% & Devamı & f & \% \\
\hline 1. Tarih & 40 & 33 & 10. Milli Güvenlik & 2 & 2 \\
2. Coğrafya & 35 & 29 & 11. Antropoloji & 1 & 1 \\
3. Vatandaşlık & 11 & 9 & 12. Edebiyat & 1 & 1 \\
4. Felsefe & 8 & 6 & 13. Ekonomi & 1 & 1 \\
5. Psikoloji & 4 & 3 & 14. Güncel Bilgiler & 1 & 1 \\
6. Sosyoloji & 4 & 3 & 15. Hukuk & 1 & 1 \\
7. Toplum/Yaşam Becerileri & 4 & 3 & 16. Matematik & 1 & 1 \\
8. İnsan ilişkileri & 3 & 2 & 17. Sanat Tarihi & 1 & 1 \\
9. Kültür & 2 & 2 & 18. Teknoloji & 1 & 1 \\
\hline Toplam & \multicolumn{1}{|l}{}
\end{tabular}

Tablo 5'te "Sosyal bilgiler dersinin içeriğini neler oluşturmaktadır?" sorusundan elde edilen bulgulara göre katılımcıların sosyal bilgiler dersinin içeriğine ilişkin mevcut algılarının başında \%33 ile "Tarih" ve \%29 ile "Coğrafya" gelmektedir.

Tablo 5 incelendiğinde öğretmenlerin sosyal bilgilerin içeriğine yönelik görüşlerinin Tablo 3 'teki sosyal bilgiler görüşleri ile uyuştuğu görülmektedir. Katılımcılar sosyal bilgileri ağırlıklı olarak tarih, coğrafya ve vatandaşlık bilgisi olarak algıladıkları ve sosyal bilgiler içerisinde yer alan diğer sosyal bilimlerden ise yeterince haberdar olmadıkları görülmektedir.

\section{Katılımcıların Okul Öncesi Ĕ̈itimde Sosyal Bilgilere İlişkin Görüşlerine Yönelik Bulgular} Katılımcıların okul öncesi eğitimde sosyal bilgilerin gerekli olup olmadığına ilişkin görüşlerinden elde edilen bulgular Tablo 6' da verilmiştir.

Tablo 6. Okul Öncesinde Sosyal Bilgilerin Gerekliliğine İlişkin Bulgular

\begin{tabular}{lcc}
\hline Tema 4. Okul Öncesinde Sosyal Bilgilerin Gerekliliği & f & \% \\
\hline Gerekli & 40 & 100 \\
Gerekli değil & - & - \\
\hline Toplam & $\mathbf{4 0}$ & $\mathbf{1 0 0}$ \\
\hline
\end{tabular}

Tablo 6'ya göre katılımcıların tamamı okul öncesi eğitimde sosyal bilgilerin gerekli olduğunu ifade ettikleri görülmektedir. Katılımcıların okul öncesi eğitimde sosyal bilgilerin gerekliliğine ilişkin görüşleri ise şöyledir: 
"Gereklidir. Etkinliklerimiz içerisinde de yer veriyoruz. Çocuğun kendini tanıması, ailesini tanıması, anne babasının mesleğini söyleyerek bilgi vermesi gibi. ... Sadece kendini ifade etmesi için değil en azından yakın çevresini okulunu evini gittiği belli başlı yerleri tanıması açısından da önemlidir."(Ceylan); "Gereklidir. Tabi ki biz bir tarihi ciddi anlamda çocuklara veremiyoruz ama Atatürk'ün hayatından bahsediyoruz. Bir gezi alanına bir müzeye bir bilim merkezine giderek sosyal ortamlara sokarak yavaş yavaş veriyoruz aslında. Drama ile toplumdaki farkl rolleri farkl kültürlerin ne gibi alışkanlıkları var ögreniyoruz. Aslında bunları öğretiyoruz. 亡yi bir vatandaş diyoruz en başta temelde burada atıldı̆̆ için bence mutlaka gereklidir." (Duru).

Tablo 6 ve katılımcılardan sağlanan doğrudan alıntılar incelendiğinde katılımcıların tamamının okul öncesi eğitimde sosyal bilgilerin gerekliliğine inandıkları ve somut olarak yer almasını istedikleri ifade edilebilir.

\section{Katılımcıların Sosyal Bilgilere Yönelik Gerçekleştirdikleri Etkinliklere İlişsin Bulgular}

Katılımcıların okul öncesi eğitimde sosyal bilgilere yönelik hangi etkinlikleri gerçekleştirdiklerine yönelik elde edilen bulgular Tablo 7 ve Tablo 8'de yer almaktadır. Tablo 7'de katılımcıların derslerinde sosyal bilgilere yönelik gerçekleştirdikleri etkinliklere yer verilmiştir.

Tablo 7. Öğretmenlerin Sosyal Bilgilere Yönelik Etkinliklerine İlişkin Bulgular

\begin{tabular}{lcc}
\hline Tema 5. Öğretmenlerin Sosyal Bilgiler İçerikli Etkinlikleri & f & $\mathbf{\%}$ \\
\hline Coğrafya Etkinlikleri & $\mathbf{3 8}$ & $\mathbf{3 7}$ \\
\hline 1. İklim ve hava gözlemi & 15 & 15 \\
2. Harita çalışmaları & 7 & 7 \\
3. Uzay ve gezegenler & 5 & 5 \\
4. Yaşam döngüsü & 4 & 4 \\
5. Yanardağ deneyi & 3 & 3 \\
6. Erozyon deneyi & 2 & 2 \\
7. Ağaç dikme & 2 & 2 \\
\hline Tarih Etkinlikleri & $\mathbf{2 7}$ & $\mathbf{2 6}$ \\
\hline 8. Önemli Türk Büyükleri & 13 & 13 \\
9. Atatürk etkinlikleri & 12 & 12 \\
10. Zaman ve Kronoloji & 2 & 2 \\
11. Soyağaci oluşturma & 1 & 1 \\
\hline Vatandaşlk Etkinlikleri & $\mathbf{8}$ & $\mathbf{8}$ \\
\hline 11. Toplumda uyulması gereken kurallar & 5 & 5 \\
12. Seçim ve oy kullanma & 2 & 2 \\
14. Çocuk Hakları & 1 & 1 \\
\hline Okul Dişı Etkinlikler & $\mathbf{1 1}$ & $\mathbf{1 1}$ \\
\hline 15. Gezi-gözlem & 11 & 11 \\
\hline Diğer & $\mathbf{1 8}$ & $\mathbf{1 8}$ \\
\hline 15. Belirli gün ve haftalar etkinlikleri & 11 & 11 \\
16. Drama & 7 & 7 \\
\hline Toplam & $\mathbf{1 0 2}$ & $103 / \mathbf{1 0 0}$ \\
\hline
\end{tabular}

Tablo 7'de “Derslerinizde sosyal bilgilere yönelik hangi etkinlikleri gerçekleştiriyorsunuz?" sorusuna ilişkin bulgulara yer verilmiştir. Bulgular beş kategori olarak sınıflandırılmıştır. Bunlar \%37 ile "coğrafya etkinlikleri”, \%26 ile "tarih etkinlikleri”, \%8 "vatandaşlik etkinlikleri", \%11 "okul dişı etkinlikler" ve \%18 ise "diğer" (drama/belirli gün ve haftalar) etkinliklerdir. Belirtildiği üzere katılımcıların sosyal bilgilere yönelik gerçekleştirdikleri etkinliklerin başında "coğrafya etkinlikleri”" gelmektedir. Coğrafya etkinliklerinin başında ise 
"iklim ve hava gözlemi” (f:15) yer almaktadır. Bunun dışında sırasıyla "harita çalışmaları", "uzay ve gezegenler", "yaşam döngüsü”, "yanardağ deneyi”, "erozyon deneyi” ve "ağaç dikme" etkinlikleri bulunmaktadır

Katılımcıların ikinci olarak en fazla gerçekleştirdikleri sosyal bilgiler etkinlikleri "tarih etkinlikleri"dir. Katılımcıların tarih etkinlikleri olarak dile getirmiş oldukları başlıca etkinlikler “önemli Türk büyükleri” ve "Atatürk etkinlikleri”'dir. Bunlar dışında bazı katılımcıların ise “zaman ve kronoloji”ye yönelik etkinlikler gerçekleştirdikleri tespit edilmiştir. Gerçekleştirilen etkinliklere yönelik bazı öğretmen görüşleri ise şu şekildedir:

"Harita etkinliklerimiz oluyor. Belirli günlerde genelde sanat etkinlikleriyle yapıyoruz. Örneğin harita nedir öncelikle bunu konuşuyoruz. Haritadaki renkler neyi ifade eder bunu gösteriyoruz. ..." (Hayriye); "Yanardağ deneyi yaptırmıştık. ... Soy ă̆acı ile ilgili etkinlik yapmıştık. ... Çevre incelemeleri yaptırlyoruz. Geziler düzenliyoruz. ... Yakın çevrede mesleklerle alakalı gezi-gözlem yapıyoruz." (Melis); "Ülkemizi yaşadı̆̆ coğrafyay, millî bilinci anlatıyoruz. Türkiye haritası yaptık. Haritamı üzerinden Kayseri’yi gösterdiler. Kazanımlarımız doğrultusunda Atatürk konusuna yer verdiğimiz oluyor. Atatürk ile ilgili anı albümü yaptık. ... Erozyon deneyi yaptık.” (Remziye); “... Uyguladığımız projeler var Büyük Türkler projesi var. Tarihimizde önemli ilim, bilim felsefe alanında isim yapmış adı dünyaya yazılmış Türkleri çocuklarla tanıyoruz. İbn-i Sina, Farabi, Mevlâna, Mimar Sinan gibi çocukların çok ilgi duyduğu bir proje bu. 15 günde bir uyguluyoruz bu projeyi. ..." (Oya).

Tablo 7 ve öğretmen görüşleri incelendiğinde katılımcıların çoğunluğunun sosyal bilgilere yönelik benzer etkinlikler yaptıklarını, bununla birlikte okul öncesi eğitimde sosyal bilgiler kapsamına dâhil edilebilecek etkinlikleri sıklıkla kullandıkları ifade edilebilir. Okul öncesi öğretmenlerinin sosyal bilgiler bağlamında okul öncesi eğitimde hangi sınıf/okul dış1 uygulamaları gerçekleştirdiklerine ilişkin bulgular ise Tablo 8'de verilmiştir.

Tablo 8. Gerçekleştirilen Sınıf/Okul Dışı Etkinliklere İlişkin Bulgular

\begin{tabular}{lcc|lcc}
\hline $\begin{array}{l}\text { Tema 6. Sinıf/Okul Dışı } \\
\text { Etkinlikler }\end{array}$ & $\mathbf{f}$ & $\boldsymbol{\%}$ & Devamı & $\mathbf{f}$ & \% \\
\hline 1. Okul Bahçesi & 23 & 18 & 11. Kızılay Merkezi & 2 & 2 \\
2. Müzeler & 22 & 17 & 12. Veli Ev Ziyareti & 1 & 1 \\
3. Sinema & 17 & 13 & 13. Havaalanı & 1 & 1 \\
4. Tiyatro & 16 & 12 & 14. Ilkokul & 1 & 1 \\
5. Bilim Merkezi & 15 & 12 & 15. Oyun Alanı & 1 & 1 \\
6. Hayvanat Bahçesi & 8 & 6 & 16. Şenlikler & 1 & 1 \\
7. Kütüphane & 7 & 5 & 17. Yapılmayan & 2 & 2 \\
8. Meslek Ziyaretleri (Firın vb.) & 6 & 5 & 11. Kizılay Merkezi & 2 & 2 \\
9. Çiftlikler & 3 & 2 & 12. Veli Ev Ziyareti & 1 & 1 \\
10. Spor Merkezi & 3 & 2 & & & $\mathbf{1 2 9}$
\end{tabular}

Tablo 8'e göre, katılımcıların sosyal bilgiler kapsamında en sık gerçekleştirdikleri sınıf/okul dışı etkinliklerin \%18 ile "okul bahçesi", \%17 ile "müzeler", \%13 ile "sinema", \%12 ile "tiyatro" ve \%12 ile "bilim merkezi" etkinlikleri olduğu görülmektedir. Öğretmenlerin sınıf/okul dışı etkinliklere ilişkin görüşlerinden bazıları şöyledir:

“... Havaalanina gezimiz oluyor. Atatürk Evi'ne gittik. Etnografya Müzesi'ne gittik. ...” (Jale); "Bahçede uyguladığımız Sera Projesi var. Binicilik var. ... Bunlar tabi ki hep 
okulumuzun uyguladığı projelerdir. ... Çok fazla alan gezimiz var. Özellikle büyük Türklerle ilgili alan gezileri yapıyoruz. Örneğin; Ağırnas'a gidiyoruz Mimar Sinan Evi'ni ziyarete. Gevher Nesibe Müzesi'ne ve iki hafta önce Millî Mücadele Müzesi'ne gittik. Etnografya Müzesi'ne gidiyoruz. Talas'ta ki yeralt şehrine gidiyoruz. Yani gidebildiğimiz her yere gidiyoruz. Onun dışında sinema tiyatroya da gidiyoruz." (Oya).

"Bahçede hareketli oyun etkinlikleri ve doğa etkinlikleri yaptırıyoruz. ... En son bilim merkezine gittik. ... Deprem simülasyonuna girdiler. Hortum simülasyonuna girdiler. Onun dışında hayvan bitki ve fosilleri incelediler. Her sene bir kere müze gezimiz oluyor. Etnografya Müzesi'ne gitmiştik. Orada bahçedeki ve müzedeki eski yapıları inceliyoruz. Eski Kayseri evlerini geziyoruz. Pikniklerimiz oluyor, uçurtma şenliklerimiz oluyor." (Nuran); "En son bilim merkezine gittik. Orada mesela uzaydan gökyüzüne her şeyin somut örneği var. Küçücük çocuklar bile o kadar hayranlıkla izlediler ki. ... Kayseri Millı Mücadele Müzesi'ne gittik. ... Komando Müzesi var oraya gittik.” (İrem).

Tablo 8'de yer alan bilgiler ve katılımcı görüşleri incelendiğinde yaparak ve yaşayarak öğrenme yaklaşımının daha da bir önem atfettiği okul öncesi eğitim kurumlarında okul dışı etkinliklerden mevsim şartlarına göre sıklıkla yararlanıldığı söylenebilir. 40 katılımcının 129 unsur belirtmesi bu durumu kanitlar niteliktedir.

\section{Katılımcıların Sosyal Bilgilere Yönelik Etkinlik Planlarken Dikkat Ettikleri Unsurlara Illişkin Bulgular}

Katılımcıların sosyal bilgilere yönelik ders içi etkinliklerini planlarken dikkat ettikleri unsurlara ilişkin bulgular Tablo 9'da verilmiştir.

Tablo 9. Öğretmenlerin Etkinlikleri Planlarken Dikkat Ettikleri Unsurlara İlişkin Bulgular

\begin{tabular}{lcc}
\hline Tema 7. Etkinlik Planlamada Dikkat Edilen Unsurlar & f & \% \\
\hline 1. Öğrencilerin gelişim seviyeleri & 30 & 37 \\
2. Öğrencilerin ilgi, istek ve ihtiyaçları & 21 & 26 \\
3. Okul Öncesi Eğitim Programı & 11 & 14 \\
4. Çevrenin ihtiyaçları & 7 & 9 \\
5. Öğrencilerin hazırbulunuşlukları & 6 & 8 \\
6. Mevsim şartları & 3 & 4 \\
7. Okulun istek ve imkânları & 2 & 2 \\
\hline Toplam & $\mathbf{8 0}$ & $\mathbf{1 0 0}$ \\
\hline
\end{tabular}

Tablo 9'da belirtildiği üzere okul öncesi öğretmenlerin ders içi etkinliklerini planlarken dikkat ettikleri unsurların başında \%30 ile "öğrencilerin gelişim seviyelerine göre" ile \%26 ile “öğrencilerin ilgi, istek ve ihtiyaçları” gelmektedir.

Konu hakkında Ö6 "Kazanımları daha çok öğrencilerimin ihtiyaçlarına göre seçiyorum. Bazı gruplarda sosyal duygusal kazanımlara ihtiyaç duyulurken bazı gruplarda bilişsel kazanımlara ihtiyaç duyuluyor. Bu ögrenci grubunun dinamiğine bağll. ..." demiştir. Selin ise "Belirli kazanımlarımız var bu kazanımlar üzerinde çocukların ilgi ve istekleri üzerinden planlamalar yapıyoruz. ..." derken, benzer şekilde Buse "Daha çok çocukların yaş düzeylerine, ilgi ve ihtiyaçlarına göre günlük planlarımızı belirliyoruz. Ama önce çocuk önemlidir. Çocuklara göre esneklik ve değişiklik yapabiliyoruz." demiştir. Etkinliklerini planlarken birçok unsura göz önüne aldığını ifade eden Elif ise "Kazanımları öncelikle (öğrencilerin) hazırbulunuşluklarına göre seçiyorum. Yaşadı̆̆ımız kültüre göre, mevsime göre, çevreye göre seçiyorum" demiştir. 
Tablo 9'da yer alan bulgular ile öğretmen görüşlerinden alınan doğrudan alıntılar incelendiğinde; okul öncesi öğretmenlerinin etkinliklerini planlarken öncelikle görev yaptıkları sınıflardaki öğrencileri merkeze aldıkları ve bu kapsamda sabit bir programdan ilerlemedikleri görülmektedir.

\section{Katılımcıların Belirli Gün ve Haftalardan Yararlanmaya İlişkin Görüşlerine Yönelik Bulgular}

Okul öncesi öğretmenlerinin okul öncesi eğitimde belirli gün ve haftalardan yararlanmaya ilişkin görüşleri yönelik bulgular Tablo 10'da yer almaktadır.

Tablo 10. Okul Öncesi Eğitimde Belirli Gün ve Haftaların Önemine İlişkin Bulgular

\begin{tabular}{|c|c|c|}
\hline Tema 8. Belirli Gün ve Haftaların Önemi & f & $\%$ \\
\hline Önemli & 40 & 100 \\
\hline $\begin{array}{l}\text { 1. O günün/haftanın konusuna ilişkin bilinç ve farkındalık } \\
\text { kazandırdığ } 1 \text { için }\end{array}$ & 32 & 51 \\
\hline 2. Bilgileri somutlaştırma ve kalıcı öğrenmeler sağladığı için & 20 & 31 \\
\hline 3. Toplumsal değerleri aktardığı için & 8 & 13 \\
\hline 4. Öğretmenlere öğretme sürecince kolaylık sağladığı için & 3 & 5 \\
\hline Önemsiz & - & - \\
\hline Toplam & 63 & 100 \\
\hline
\end{tabular}

Tablo 10'da okul öncesi öğretmenlerinin belirli gün ve haftalardan yararlanmaya ilişkin görüşlerinden elde edilen bulgular incelendiğinde katılımcıların tamamının okul öncesi eğitimde belirli gün ve haftalardan yararlanmanın önemli olduğunu düşündükleri görülmektedir. Katılımcılar okul öncesi eğitimde "o günün/haftanın konusuna ilişkin bilinç ve farkındalık kazandırdığı için (\%51)"; "bilgileri somutlaştırma ve kalıcı öğrenmeler sağladığ1 için (\%31)" belirli gün ve haftaları önemli görmektedirler. Katılımcılar belirli gün ve haftaları önemli görmelerinin nedenlerini ise şu şekilde açıklamaktadırlar:

"Çok önemlidir çünkü çocuğun ilk algısını oluşturuyorsun, ilk defa senden duyuyor. ... Çocuklar kazanıyorlar davranışları örneğin; barkot okumayı ögrendiler ve okulda bir çocuğu çevirseniz barkodu okur Türk malı olup olmadığını size söyler. Bizler bilinçlendikçe biz de çocuklarımıza anlatıyoruz. Ülkemizle ilgili vatan sevgisini aşılamaya çalışlyoruz." (Jale); "Hem ilkokula hem de ömürlük bir hayata hazırlıyor diyebilirim. Aslında belirli gün ve haftalar ögretmenin de işini kolaylaştıran bir şey. Bir konunun varlı̆̆ çocuklara o de ğerleri kazandırmamızda yardımcı oluyor. Çocuklar bu belirli gün ve haftalarda bazı şeylerin önemini anlyorlar. Örneğin; Cumhuriyet nedir? diye sorduğumda seçimdir, oylamadır ögretmenim diyorlar. Bu bile yetiyor kazanım olarak." (Olcay)

Tablo 10 ve öğretmen görüşlerinden hareketle okul öncesi eğitimde belirli gün ve haftalardan yararlanmanın hem öğrenci hem de öğretmen açısından önemli bir faktör olduğu söylenebilir.

\section{Katılımcıların Okul Öncesi Ĕ̆itimde Önemli Gördükleri Değerlere İlişkin Bulgular}

Katılımcıların okul öncesi eğitimde verilmesini düşündükleri en önemli üç değere ilişkin bulgular Tablo 11'de gösterilmektedir. 
Tablo 11. Öğretmenlerin Okul Öncesi Eğitimde Önem Verdikleri Değerlere İlişkin Bulgular

\begin{tabular}{|c|c|c|c|c|c|}
\hline Tema 9. Önem Verilen Değerler & f & $\%$ & Devamı & f & $\%$ \\
\hline 1. Sayg1 & 30 & 25 & 9. Empati & 2 & 2 \\
\hline 2. Sevgi & 24 & 20 & 10. Nezaket & 2 & 2 \\
\hline 3. Paylaşma & 13 & 11 & 11. Adalet & 1 & 1 \\
\hline 4. Hoşgörü & 12 & 10 & 12. Ait olma & 1 & 1 \\
\hline 5. Sorumluluk & 11 & 9 & 13. Duyarlılık & 1 & 1 \\
\hline 6. Yardımseverlik & 10 & 8 & 14. Güven & 1 & 1 \\
\hline 7. Vatanseverlik & 6 & 5 & 15. Sabir & 1 & 1 \\
\hline 8. Özgüven & 4 & 3 & & & \\
\hline Toplam & & & & 119 & 100 \\
\hline
\end{tabular}

Tablo 11'e göre katılımcıların okul öncesi eğitimde önem verildikleri değerlerin en başında \%25 ile "saygı" değeri bulunmaktadır. Katılımcılar tarafından önem verilen bir diğer değer ise \%20 ile "sevgi"dir. Bu değerlere yönelik bazı öğretmen görüşleri ise şöyledir:

"Biz de ğerler eğitimine çok önem veririz. Her sınıfimızın ismi bir değerin ismini taşır. Saygl, sevgi, hoşgörü sınıfı gibi. Değerler eğitimine yönelik hikâyelerimiz var. Her ay bir dĕger alırı onu işleriz. Aile katılımlı değerlerle ilgili etkinliklerimiz var. ..." (Jale); "Hiç taviz vermeden her gün birbirimize güler yüzle merhaba, nasılsın, evde neler yaptınız gibi birbirimize soruyoruz. Günaydın, iyi akşamlar demeyi unutmuyoruz. ... Mutlaka arkadaşlarından özür dilemeyi ögrenmesini sağllyorum. ....” (Hayriye).

Tablo 11 ve katılımcı görüşleri incelendiğinde okul öncesi eğitimde değerler öğretiminin önemli bir rol oynadığı ve öğretmenlerin daha çok evrensel değerleri öğretme çabası içinde oldukları ifade edilebilir.

\section{Katılımcıların Etkili Vatandaşa Yönelik Düşünce ve Uygulamalarına İlişkin Bulgular} Okul öncesi öğretmenlerinin etkili vatandaşa ilişkin düşüncelerine yönelik bulgular Tablo 12 'de verilmiştir.

Tablo 12. Öğretmenlerin Etkili Vatandaşa İlişkin Düşüncelerine Yönelik Bulgular

\begin{tabular}{|c|c|c|c|c|c|}
\hline Tema 10. Etkili Vatandaş Algısı & $\mathbf{f}$ & $\%$ & Devamı & $\mathbf{f}$ & $\%$ \\
\hline 1. Hak ve sorumluluklarını bilen & 14 & 19 & 11. Çevresiyle iletişimi iyi & 1 & 1 \\
\hline 2. Çevresine karşı duyarlı olan & 10 & 14 & 12. Doğaya saygılı & 1 & 1 \\
\hline 3. Ülkesi için üreten ve hizmet eden & 10 & 14 & 13. Günceli takip eden & 1 & 1 \\
\hline 4. Sorumluluklarını yerine getiren & 7 & 10 & 14. Hoşgörü sahibi & 1 & 1 \\
\hline 5. Başkasının haklarına saygılı olan & 7 & 10 & 15. İşbirliğine açık olan & 1 & 1 \\
\hline 6. Vatanını seven & 6 & 8 & 16. Merhametli & 1 & 1 \\
\hline 7. Başkasına zarar vermeyen & 3 & 4 & 17. Milli bilinç sahibi & 1 & 1 \\
\hline 8. Toplumsal değerlere sahip olan & 3 & 4 & 18. Problem çözebilen & 1 & 1 \\
\hline 9. Bencil olmayan & 2 & 3 & 19. Tarihini bilen & 1 & 1 \\
\hline 10. Empati kurabilen & 2 & 3 & 20. Yardımsever & 1 & 1 \\
\hline
\end{tabular}

Tablo 12'ye göre katılımcılar etkili vatandaş1 "hak ve sorumluluklarını bilen (\%19)", "çevresine karşı duyarlı olan (\%14)", "ülkesi için üreten ve hizmet eden (\%14)", "sorumluluklarını yerine getiren (\%10)", "başkasının haklarına saygılı olan (\%10)" ve "vatanını seven (\%8)" şeklinde düşünmektedirler. Bazı katılımcıların etkili vatandaşa ilişkin görüşleri şöyledir:

"Ülkesini seven, ülkesinin sorunlarılla ilgilenen ve bunun için de gerçekten bir çaba gösteren insandır. Sadece kendini kurtaran insan değil, yaşadığ çevreye de faydası olan ve oradaki 
sorunları görüp aktif olarak çözüm üretebilen kişiler aktif vatandaşlardır." (Peri); "Her şeyiyle örnek olan kişidir...” (Olcay) olarak etkili vatandaşı tanımlamıştır. Katılımcıların öğrencilerini etkili vatandaş olarak yetiştirmek için yaptıkları çalışmalara ilişkin görüşleri ise şu şekildedir:

“Öncelikle verdiğim sözü tutuyorum. Bu yaş gurubu için öncelik rol model olmaktır. ... Bir çizgi film izlenecekse oylama yaparak seçtiriyoruz.” (Olcay); “Öncelikle kendilerini doğru ifade edebilmelerini sağllyorum. Toplum içinde nasıl konuşulur, nasıl yapmamız gerekir. ..." (Derya); "Onlara söz hakkl veriyorum. Kapıdan girdiğinde günaydın demekten başllyor olay giderken iyi günler, iyi akşamlar demeye kadar varlyor. Konuşma, kendini ifade etme, özgür ortam bunlarl sağlamak önemli." (Ö17); "Hepsine aynı süreyi tanımaya çalışıyoruz. Hepsini eşit bir şekilde dinlemeye çalışıyoruz. Mesela bana şikâyete geldiklerinde kendi sorunlarını kendileri çözmeleri gerektiğini söylüyorum. Şu an küçük olabilirler ama bu şekilde temel kazanıp devam edebilirler. Başkalarının haklarına saygı duymayı öğretiyoruz. ...” (İpek); "Düşünmelerini sağlamaya çalışıyoruz. Yaptığımız etkinliklerde sorular sorarak önce bir düşünmelerini să̆liyoruz. ... Bu zihniyetle büyüdükleri zaman gelecekte etkin birer vatandaş olabilirler diye düşünüyorum." (Hasibe).

Tablo 12'ye göre katılımcıların etkili vatandaş kavramını bir veya birkaç boyut üzerinden tanımlamaları etkili vatandaşın özelliklerini yeterince bilmedikleri şeklinde yorumlanabilir. Katılımcılar öğrencilerinin etkili vatandaş olabilmeleri için ise daha çok rol model olmayı ve değerler öğretiminden yararlanmayı tercih ettikleri görülmektedir.

\section{Katılımcıların Öğrencilerin Sosyalleşmesine Yönelik Yaptıkları Uygulamalara İlişkin Bulgular}

Okul öncesi öğretmenlerinin öğrencilerinin sosyalleşmesi için yaptıkları faaliyetlere ilişkin bulgular Tablo 13'te verilmiştir.

Tablo 13. Sosyalleşmeye Yönelik Gerçekleştirilen Etkinliklere İlişkin Bulgular

\begin{tabular}{lcc}
\hline Tema 11. Öğrencilere Yönelik Sosyalleşme Etkinlikleri & f & \% \\
\hline 1. Aile ile iş birliği gerçekleştirme & 13 & 17 \\
2. Okul dişı geziler düzenleme & 12 & 15 \\
3. Görev ve sorumluluklar vererek öğrencileri cesaretlendirme & 12 & 15 \\
4. Grup oyunlarına yer verme & 10 & 13 \\
5. Bireysel olarak ilgilenme & 9 & 11 \\
6. Sosyal etkinliklere yer verme & 8 & 10 \\
7. Akran iletişimini sağlama & 6 & 8 \\
8. Projeler hazırlama ve uygulama & 3 & 4 \\
9. Hikâyeler ile düşündürme & 2 & 2 \\
10. Serbest etkinliklere yer verme & 2 & 2 \\
11. Drama çalışmaları yaptırma & 1 & 1 \\
12. Eğitici film ve animasyonlardan yararlanma & 1 & 1 \\
13. Kendi problemlerini kendilerinin çözmesine yardımcı olma & 1 & 1 \\
\hline Toplam & $\mathbf{8 0}$ & $\mathbf{1 0 0}$ \\
\hline
\end{tabular}

Tablo 13'e göre öğrencilerin sosyalleşmesi için katılımcıların \%17'si "aile ile iş birliği gerçekleştirmekte", \%15'i “okul dışı geziler düzenlemekte", \%15'i "görev ve sorumluluklar vererek öğrencileri cesaretlendirmekte", \%13'ü "grup oyunlarına yer vermekte”, \%11'i "bireysel olarak ilgilenmekte" ve \%10'u ise sosyal etkinliklere yer vermektedirler. Konuya ilişkin bazı öğretmenlerin görüşleri aşağıda yer almaktadır: 
"Geziler düzenliyoruz. 3 sınıf olduğumuz için ara ara sınıf ziyaretleri yapıyoruz. Mısır patlatıyoruz hep birlikte diğer sinıftaki çocuklarla sosyalleşsinler, kaynaşsınlar diye. ...." (Özge); “... Haftada iki gün aile katılımlar yapıyoruz. Hafta sonu veli toplantıları yapıyoruz. Hem anne hem de babalar bir arada katılabilsinler diye. Sosyalleşme sürecinde aile katılımını önemsiyoruz.” (Zeynep); “Grup oyunlarına ă̆ırlık veriyorum. Birlikte bir şeyler yapabildikçe uyumu da daha iyi oluyor. Arkadaşlarıyla paylaşması da yardımlaşması da olumlu yönde gelişiyor." (Gamze); Oya ise "En başta geziler yapıyoruz. Yaparak yaşayarak ögrenmelerini, görmelerini istiyoruz. Hayvanat bahçesinden bilim merkezine piknik alanlarına kadar görmesini istiyoruz. ... Çekingen çocukları da okul öncesinde yaşadiğı olayl, bir filmi, hikâyeyi birebir paylaşmasını istiyoruz. Açık uçlu şeyler soruyoruz anlattırıyoruz. ..." şeklinde öğrencilerin sosyalleşmelerini sağlamak amaçlı yaptıkları faaliyetleri açıklamıştır.

Tablo 13 ve bazı öğretmen görüşleri incelendiğinde okul öncesi dönemde öğrencilerin sosyalleşebilmesi için aile ile iş birliği yapıldı̆̆ı, öğrenciler cesaretlendirilerek onlara özgüven kazandırıldığı ve sık sık sosyal etkinliklerden yararlanıldığg görülmektedir.

\section{SONUÇ VE ÖNERILER}

Okul öncesi öğretmenlerinin sosyal bilgilere ilişkin görüşlerini tespit etmek amaciyla gerçekleştirilen çalışmadan elde edilen bulgulardan hareketle şu sonuçlara ulaşılmıştır:

Araştırmaya katılan okul öncesi öğretmenlerinin sosyal bilgilere ilişkin algılarının önemli bir kısmını Tarih Öğretimi, Coğrafya Öğretimi ve Vatandaşlık Bilgisi'nin oluşturduğu belirlenmiştir. Bu sonuç beklenen ve alanyazın ile paralellik gösteren bir durumdur. Çünkü sosyal bilgiler dersi geçmişten günümüze sahip olduğu öğretim programları, tarih, coğrafya ve vatandaşlık bilgisi ağırlıklı bir içeriğe sahip olmuştur. Öğretmen görüşleri incelendiğinde öğretmenlerin büyük bölümü sosyal bilgilere ilişkin algılarını ifade ederken Tarih ve Coğrafya'yı birlikte kullandıkları gözlemlenmiştir. Bu durumu Güler ve Tuğrul (2007) yapmış oldukları çalışmada tarih ve coğrafya sosyal bilimlerin birbirini tamamlayan iki önemli alan olduğunu, çocukların coğrafya ve tarihle ilgili etkinlikler sayesinde; olayların ve yerlerin zaman karşısında birbirlerini nasıl etkilediğini, insanların kendi çevrelerini geçmişin farklı dönemlerinde nasıl etkiledikleri ya da çevrelerinden nasıl etkilendiklerini öğrendiklerini ifade ederek her iki disiplinin birbirinden ayrı düşünülemeyeceğini ortaya koymuştur. Ancak sosyal bilgiler dersinin içeriğinin ve kapsamının çok geniş bir alanı kapsamasına rağmen araştırmaya katılan okul öncesi öğretmenlerinin algılarının çoğunlukla tarih, coğrafya ve vatandaşlık bilgisi odaklanması bir eksiklik olarak ifade edilebilir. Ancak Şimşek-Çetin ve Akhan (2015) çalışmasında okul öncesi öğretmen adaylarından sosyal bilimleri açıklamalarını istediklerinde, sosyal bilimleri doğru ve anlaşılır şekilde açıkladıklarını tespit etmişlerdir.

Çalışma grubunda yer alan okul öncesi öğretmenlerinin geçmiş öğrenim yaşantılarında sosyal bilgiler dersine karşı tutumlarının olumlu olduğu, bunun nedeninin ise dersin içeriğine karşı olan ilgiden kaynaklandığı ortaya çıkmıştır. Benzer şekilde Şimşek-Çetin ve Akhan'da (2015) yapmış oldukları çalışmada okul öncesi öğretmen adaylarının kendilerine en yakın hissettikleri alanların başında sosyal bilimlerin geldiğini ve bunun nedeninin ise alana karşı ilgiden kaynaklandığını ve sosyal bilimler ile ilgili olumlu metaforlar geliştirdiklerini tespit etmişlerdir. Akhan ve Şimşek-Çetin (2015) de okul öncesi öğretmen adaylarının sosyal bilgiler eğitimine yönelik ilgi düzeylerinin yüksek olduğunu ve sosyal bilgiler eğitimi üzerine görüşlerinin olumlu olduğunu tespit etmişlerdir. 
Araştırmaya katılan 40 okul öncesi öğretmeninin sosyal bilgiler dersinin içeriğine ilişkin mevcut algılarının ağırlıklı olarak Tarih, Coğrafya ve Vatandaşlık'tan oluştuğu, ancak katılımcıların sosyal bilgiler içerisinde yer alan diğer sosyal bilimlerden yeterince haberdar olmadıkları tespit edilmiştir. Araştırmaya katılan okul öncesi öğretmenlerinin sosyal bilgiler dersinin içeriğine ilişkin mevcut algılarının ağırlıklı olarak Tarih, Coğrafya ve Vatandaşlık'tan oluştuğu, ancak katılımcıların sosyal bilgiler içerisinde yer alan diğer sosyal bilimlerden yeterince haberdar olmadıkları tespit edilmiştir. Bu bulgular araştırmanın ilk sonuç maddesi olan "sosyal bilgiler algısı" ile örtüşmektedir.

Araştırmaya katılan okul öncesi öğretmenlerinin tamamı okul öncesi eğitimde sosyal bilgilerin gerekli olduğunu ve bu nedenle okul öncesi eğitimde sosyal bilgilerin yer alması gerektiğini düşündükleri belirlenmiştir. Akhan ve Şimşek-Çetin'de (2015) okul öncesi öğretmen adayların kendi lisans programları ve okul öncesi dönem için sosyal bilgiler eğitimini gerekli bulduklarını tespit etmiştir. Şimşek-Çetin ve Akhan'da (2015) çalışmada yer alan tüm katılımcıların okul öncesi dönemde tarih ve coğrafya disiplinleri ile ilgili olarak etkinliklere yer verilmesi yönünde görüş bildirdiği tespit edilmiştir. Ünlü ve Alkış’da (2006) okul öncesi öğretmen adaylarının coğrafi olayları neden sonuç ilişkileri kurarak açıklayabilmesi, coğrafya temel kavramlarını bilmesi hem Türkiye hem de Dünya coğrafyası hakkında bilgi sahibi olmaları gerektiğini ve okul öncesi çocuklarının gereksinimlerine cevap verebilecek nitelikte öğretmenler yetiştirmek için okul öncesi öğretmenliği lisans programlarında coğrafya derslerinin yer alması gerektiğini belirtmişlerdir. Bu açıdan gerek hizmet-içi gerekse de hizmet-öncesi öğretmenlerin okul öncesi eğitimde sosyal bilgilerin yer alması gerektiğini düşündükleri söylenebilir.

Okul öncesi öğretmenleri ders etkinliklerini planlarken dikkate aldıkları unsurların başında öğrencilerin ilgi, istek ve ihtiyaçları gelmektedir. Bu beklendik bir sonuç olmakla birlikte istendik de bir gelişmedir. Çünkü genelde eğitim özelde ise okul öncesi eğitimde her çocuğun bireysel özellikleri dikkate alınmalıdır. Bu doğrultuda hazırlanacak etkinliklerde çocukların gelişimsel ve bilişsel özellikleri dikkate alınmalıdır. Bu durum özellikle okul öncesi eğitimde daha da bir önem kazanmaktadır. Bu doğrultuda MEB (2013a) Okul Öncesi Eğitim Programı Etkinlik Kitabı'nda sunulan etkinliklerin öğretmenlere örnek olması amacıyla hazırlandığını ve öğretmenlerin sınıflarındaki çocukların gelişimlerini desteklemek amacıyla hangi etkinliklere ihtiyaç duyuyorlarsa onları kullanarak yeni etkinlikler geliştirmelerini ve verilen bu etkinlik havuzunu zenginleştirmelerini istemektedir.

Araştırma sonucunda okul öncesi öğretmenlerinin sosyal bilgiler kapsamında en fazla gerçekleştirdikleri etkinliklerin başında Coğrafya etkinliklerinin geldiği; Coğrafya etkinliklerinin başında ise "İklim ve hava gözlemi” nin geldiği tespit edilmiştir. Bunun dışında en sık gerçekleştirilen diğer coğrafya etkinlikleri ise sırasıyla "Harita çalışmaları", "Uzay ve gezegenler", "Yaşam döngüsü", "Yanardağ deneyi", "Erozyon deneyi” şeklindedir. Ünlü (2001) de yapmış olduğu çalışmada okul öncesi eğitim programının coğrafya öğretimi ile uyumlu olduğunu, programda olan coğrafya konularının dünya, hava, toprak, bitkiler, su, doğa ve orman, hayvanlar, mevsimler, mevsimlerin özellikleri, uzay, güneş, insan, gece-gündüz, zaman, gökyüzü, yerleşme ve çevre şeklinde çok zengin olduğunu ve kavramların işlenişlerinin tamamen bir coğrafi anlayış içerisinde, ünite ve konu bütünlügü şeklinde bulunduğunu ifade etmiştir. Öztürk, Giren, Yıldırım ve Şimşek (2015) de okul öncesi dönemde coğrafya eğitiminde 6 temel bilim alanının (konum, yer, hareket, insan, çevre etkileşimi ve bölge) güncellenen Okul Öncesi Eğitim Programı'nın (2013) içeriğinde yer aldığını belirlemiş ve bu temel bilim alanlarının program içerisinde kazanım göstergelerde, kavramlarda veya belirli gün haftalarda yer aldığını tespit etmiştir. 
Araştırma sonucunda okul öncesi eğitimde sosyal bilgilere yönelik en fazla gerçekleştirilen etkinliklerden biri de "Tarih Etkinlikleri"nin olduğu; gerçekleştirilen tarih etkinliklerinden başında ise "Önemli Türk Büyükleri" ve "Atatürk etkinlikleri”nin geldiği belirlenmiştir. Aktın ve Dilek (2014), okul öncesi dönemde tarih öğretiminin çocukların kendisiyle bağlantılı olarak, yakından uzağa şeklinde ailesi, komşuları, toplum, devlet, ulus, dünya ve evren ile ilgili somut konular ve değerler üzerine genişlediğini tespit etmişlerdir. Ayrıca tarihsel öğrenmelerin kapsamının ise genellikle çocukların kendisi ve ailesi ile ilgili geçmişlik içeren olaylar, ülkelerinin, bölgelerinin resmi ve dini tatil günleri ve ülkenin tarihi kahramanlarından oluştuğunu belirtmişlerdir.

Okul öncesi eğitim kapsamında gerçekleştirilen etkinliklerden bir diğerinin ise "Okul D1ş1 Etkinlikler" olduğu. Bu kapsamda ise öğretmenlerin "Gezi-gözlem ziyaretleri" ve "Belirli gün ve haftalar etkinlikleri” gerçekleştirdikleri ortaya çıkmıştır. Okul dışı etkinlikler okul öncesi eğitimde birçok farklı amaç için kullanılabilmektedir. Katılımcı görüşleri incelendiğinde de bu faaliyetlerin önemli bir kısmının sosyal bilgilere yönelik olduğu görülmüştür. Aktaş-Arnas (2007) da çalışmasında okul öncesi eğitimde sınıfa getirilemeyen olay ve durumların yerinde incelenmesi ve gözlenmesi amacıyla geziler düzenlenebileceğini; bu geziler ile çocukların gözlem yapacakları durumları doğal ortamlarında görme fırsatı yakalayacaklarını ve çocukların keşfederek öğrenmesine olanak vereceğini ifade etmiştir.

Araştırma kapsamında ortaya çıkan sosyal bilgiler kapsamında gerçekleştirilen etkinlik türlerinden bir diğeri ise "Vatandaşlık Etkinlikleri"nin olduğu ve bu kapsamda öğretmenlerin "Toplumda uyulması gereken kurallar", "Seçim ve oy kullanma" ve "Soyağacı oluşturma" etkinliklerini gerçekleştirdiği tespit edilmiştir. Bu kapsamda okul öncesi eğitimde vatandaşlık etkinliklerine yeterince yer verilmediği söylenebilir. Bunun başlıca nedenlerinden birisinin de okul öncesi eğitim programında ve ona bağlı olarak etkinlik kitabında vatandaşlık alanına yer verilmemesinden kaynaklandığı söylenebilir. Oysaki "Avrupa Konseyi Demokratik Vatandaşlık Eğitimi ve İnsan Hakları Eğitimi Şartı" (Avrupa Konseyi, 2010) raporunda üye ülkelerin demokratik vatandaşlık ve insan hakları eğitimini okul öncesi eğitimden itibaren öğretim programlarına dâhil etmeleri gerektiğini tavsiye karar olarak ifade edilmiştir. Vatandaşlık eğitimi, ulus vatandaşlığı ve küresel/dünya vatandaşlığ alınabilmektedir. Ceylan (2014) ise yaptığı araştırmada okul öncesi öğretmenlerin büyük bir kısmının okul öncesi eğitim programının dünya vatandaşlığını içermesi gerektiğini, çocuklara dünya vatandaşlığını öğretmek istediklerini, ancak aldıkları öğretmen eğitiminin çocuklara dünya vatandaşlığını öğretmek için yetersiz olduğunu ifade etmişlerdir. Araştırma sonucunda okul öncesi öğretmenlerinin sosyal bilgiler kapsamına dâhil edilebilecek etkinlikleri sıklıkla gerçekleştirdikleri ortaya çıkmıştır.

Araştırma sonucunda okul öncesi öğretmenlerinin sosyal bilgiler kapsamında gerçekleştirdikleri başlıca sınıf/okul dışı etkinliklerin sırasıyla Okul Bahçesi, Müzeler, Sinema, Tiyatro ve Bilim Merkezi'nin olduğu tespit edilmiştir. Bu bağlamda okul öncesi eğitim kurumlarında okul dışı etkinliklerden sıklıkla yararlanıldığı belirlenmiştir. Bu etkinliklerden sıklıkla yararlanılmasının nedeni ise öğrencilerin ilgisini çekmesinden kaynaklandığı söylenebilir. Öğretmneler okul öncesinde müzelerden sıklıkla yararlandıklarını ifade etmişlerdir. Öner ve Çengelci-Köse'nin (2019) de ifade ettiği gibi müzeler okul öncesi eğitimden yüksek öğretime kadar her kademede yararlanılabilen mekanlardan biridir. Okul öncesinde de sıklıkla yapılmasının nedeni Aktın (2017) da belirttiği gibi küçük yaşlardaki çocukların müze gezisinde çok eğlenlenmeleridir. Okul öncesi öğretmenlerinin sıklıkla yararlandıkları okul dışı ortamlardan birisi de bilim merkezleridir. Müzeler gibi okul 
öncesinden yükseköğretime kadar her kademede yararlanılabilen bilim merkezleri (Öner \& Öztürk, 2019) de sahip oldukları içeriklerle özellikle okul öncesi dönemdeki çocukların ilgi ve merakını çekmekte başarılı ortamlardan birisidir.

Araştırma sonucunda okul öncesi öğretmenlerinin tamamı okul öncesi eğitimde belirli gün ve haftalardan yararlanmanın önemli olduğunu düşündükleri tespit edilmiştir. Önemli görme nedenlerinin başında ise belirli gün ve haftaların bilgileri somutlaştırarak kalıcı öğrenmeler sağlamasından, o günün/haftanın önemini vurgulamasından ve konuya ilişkin bilinç ve farkındalık kazandırmasından kaynaklandığı tespit edilmiştir. Seefeldt, Castle ve Falconer (2015), belirli gün ve haftalar kapsamında ele alınan kutsal (milli ve dini bayramlar vb.) kutlamaların, çocuklar açısından tam anlamıyla neşeli ve dinlendirici olabileceği, aynı zamanda tarihsel bilgiyi daha gerçek ve tutarlı bir şekilde elde edilebileceğini ifade etmiştir.

Araştırmaya katılan öğretmenlerin okul öncesi eğitimde önem verdikleri değerlerin başında Sayg1 ve Sevgi'nin geldiği belirlenmiştir. Benzer şekilde Uzun ve Köse (2017) de okul öncesi öğretmenleriyle yaptıkları çalışmada değerler eğitimine okul öncesi eğitimde başlanılması gerektiğini düşündüklerini ve değerler eğitimi bağlamında sevgi, sayg1, dürüstlük, sorumluluk, vatan sevgisi, yardımlaşma, hoşgörü ve paylaşma gibi değerlere yer verdikleri sonucuna ulaşmışlardır. Uçuş-Güldalı ve Demirbaş (2017) Okul Öncesi Eğitim Programı ile Hayat Bilgisi Öğretim Programı'ndaki değerleri karşılaştırdıkları çalışmalarında Okul Öncesi Eğitim Programında yer alan sevgi, saygı, sorumluluk, dayanışma, paylaşma, hoşgörü, yardımlaşma, özgüven değerlerinin Hayat Bilgisi Öğretim Programı ile ortak değerler olduğunu tespit etmişlerdir. Aktın ve Dilek (2014) ise çocukların, öykülerdeki karakterler aracılığıyla dürüstlük, vatanseverlik, cesaret ve kararlılık gibi davranışları kavrayabileceklerini ortaya çıkarmıştır.

Araştırma sonucunda okul öncesi öğretmenlerinin etkili vatandaş algılarının sırasıyla hak ve sorumluluklarını bilen, çevresine karşı duyarlı ve faydalı olan, ülkesi için üreten ve hizmet eden, sorumluluklarını yerine getiren, başkasının haklarına saygılı olan ve vatanını seven şeklinde olduğu tespit edilmiştir. Okul öncesi öğretmenlerinin etkili vatandaşa ilişkin görüşlerinin sosyal bilgilerin temel değer ve becerileri ile uyuştuğu söylenebilir. Ancak araştırmaya katılan okul öncesi öğretmenlerinin etkili vatandaş kavramını yeterince bilmedikleri ifade edilebilir. Araştırmaya katılan öğretmenler öğrencilerinin etkili vatandaş olabilmeleri için ise daha çok rol model olmayı ve değerler öğretiminden yararlanmayı tercih ettikleri ortaya çıkmıştır. Yiğit ve Sezer (2007) ise yaptıkları çalışma sonucunda okul öncesi öğretmenlerinin çocukların eğitim sürecinde aktif olmalarına ve yapılan etkinliklerde yer almaların özen gösterdikleri, çocukların düşüncelerini özgürce dile getirmelerine ve sorumluluk almalarına önem verdiklerini tespit etmişlerdir.

Son olarak araştırma sonucunda öğretmenlerin öğrencilerin sosyalleşmesi için aile ile iş birliği gerçekleştirme, okul dışı geziler düzenleme, görev ve sorumluluklar vererek öğrencileri cesaretlendirme ve grup oyunlarına yer verdikleri belirlenmiştir. Aslanargun ve Tapan (2012) yaptıkları çalışmada sosyal ve duygusal açıdan kendini geliştiren çocukların akranları ile daha etkin iletişim kurabildiği, ailesi ve öğretmenleriyle daha kolay etkileşime geçebildiği ve dolayısıyla akademik ve sosyal olarak daha fazla doyum sağladığını ifade etmiştir. $\mathrm{Bu}$ bağlamda okul öncesi eğitimde sosyalleşmenin çeşitli etkinliklerle gerçekleştirildiği sonucuna ulaşılmıştır. 
Araştırma sonucunda şu önerilerde bulunulabilir:

- Okul öncesi eğitim programında sosyal bilgilere yönelik kazanımların sayısı artır1labilir.

- Okul öncesi eğitim programına ek olarak sosyal bilgiler etkinliklerini içeren bir paket eğitim programı hazırlanabilir.

- Okul öncesi öğretmenlerinin sosyal bilgilere ilişkin ayrıntılı bilgiye sahip olabilmesi ve gerçekleştireceği etkinlikleri daha sistematik yapabilmesi için okul öncesi öğretmenliği lisans programlarına Sosyal Bilgiler Öğretimi dersi eklenebilir. Hâlihazırda görev yapan öğretmenlere ise teorik ve uygulamaya yönelik sosyal bilgiler hizmet içi eğitimleri verilebilir.

- Millî Eğitim Bakanlığı'nın hazırladığı Okul Öncesi Eğitimi Etkinlik Kitabı'nda sosyal bilgilere veya vatandaşlığa ilişkin etkinlik örneklerine yer verilebilir.

\section{KAYNAKÇA}

Akhan, N. E. ve Şimşek-Çetin, Ö. (2015). Okul öncesi öğretmen adaylarının sosyal bilgiler eğitimine yönelik ilgilerinin ve görüşlerinin belirlenmesi. Eğitimde Kuram ve Uygulama, 11(2), 551-588.

Aktaş-Arnas, Y. (2007). Okul öncesi dönemde fen eğitimi. Kök Yayınc1lık.

Aktın, K. (2014). Okul öncesi dönemde sosyal bilgiler eğitimi: Mesleklerin öğretimine yönelik bir durum çalışması. Turkish Studies, 9(5), 139-155.

Aktın, K. (2017). Okul öncesi dönemde müze eğitimi ile çocukların tarihsel düşünme becerilerinin geliştirilmesi. Mersin Ëniversitesi Eğitim Fakültesi Dergisi, 13(2), 465-486, http://dx.doi.org/10.17860/mersinefd.336734

Aktın, K. ve Dilek, G. (2014). Tarih/Sosyal bilgiler öğretim programlarında okul öncesi dönemde tarih öğretimi: ABD örneği. Uluslararası Avrasya Sosyal Bilimler Dergisi (Prof. Dr. Refik TURAN Özel Sayısı), 5(16), 36-56.

Arslanoğlu, İ. (2016). Bilimsel yöntem ve araştırma teknikleri. Gazi Kitabevi

Aslanargun, E. ve Tapan, F. (2012). Okul öncesi eğitim ve çocuklar üzerindeki etkileri. Abant İzzet Baysal Üniversitesi Eğitim Fakültesi Dergisi, 11(2), 219-238.

Avrupa Konseyi (2010). Avrupa Konseyi Demokratik Vatandaşlık Eğitimi ve İnsan Hakları Eğitimi Şartı. https://rm.coe.int/16804884d1.

Balc1, A. (2016). Sosyal bilimlerde araştırma yöntem, teknik ve ilkeler. Pegem Akademi.

Büyüköztürk, Ş., Kıllı̧-Çakmak, E. Akgün, Özcan, E. Karadeniz, Ş. ve Demirel, F. (2009). Bilimsel araştırma yöntemleri. Pegem Akademi.

Ceylan, Ş. (2014). Okul öncesi öğretmenlerinin dünya vatandaşlı̆̆ı eğitimi ile ilgili görüşleri. Kuramsal Ĕgitimbilim Dergisi, 7(1), 78-93.

Creswell, J. W. (2015). Nitel araştırma yöntemleri, M. Bütün ve S. B. Demir (Çev. Ed.), Siyasal Kitabevi.

Çelik, M. ve Gündoğdu, K. (2007). Türkiye'de okulöncesi eğitimin tarihsel gelişimi. Atatürk Üniversitesi Kâzım Karabekir Ĕgitim Fakültesi Dergisi, 16, 172-190.

Denzin, N. K. and Lincoln, Y. S. (2005). The SAGE handbook of qualitative research. Sage Publications.

Eğitim-Bir-Sen. (2016). Eğitime bakış 2016 izleme ve değerlendirme raporu. Eğitim-Bir-Sen Yayınları: 68.

Epstein, A. S. (2014). Preschool: Social studies in preschool? Yes!, Young Children, 69(1), 78-83.

Gainsley, S. and Neill, P. (2018). Defining social studies in early childhood. HighScope, 29(1), 16-17.

Glesne, C. (2013). Nitel araştırmaya giriş, A. Ersoy ve P. Yalçınoğlu (Çev. Ed.). Anı Yayıncılık. 
Güler, T. ve Tuğrul, B. (2007). Okul öncesi çocuklarına yönelik sosyal çalışma alanında tarih ve coğrafya eğitimi. Çukurova Üniversitesi Eğitim Fakültesi Dergisi, 3(33), 29-35.

Kalkınma Bakanlı̆̆ı. (2013). Onuncu Kalkınma Planı (2014-2018). Ankara: Bakanlık Yayınları. https://kkp.tarim.gov.tr/sp/Onuncu\%20Kalk\%C4\%B1nma\%20Plan\%C4\%B1(2014-2018).pdf

$\begin{array}{lllll}\text { Kalkınma } & \text { Bakanlığı. } & \text { (2016). } & \text { Orta } & \text { Vadeli }\end{array}$ http://www.kalkinma.gov.tr/Pages/content.aspx?List=28363ffa-6f2c-4400-86bcca5decdb5161\&ID=13\&Source=http\%3A\%2F\%2Fwww\%2Ekalkinma\%2Egov\%2Etr\%2FPages\%2FOr taVadeliProgramlar\%2Easpx\&ContentTypeId=0x0100F586C93FC4CA2749A016DD998B6133D2

Karasar, N. (2015). Bilimsel araştırma yöntemi. Nobel Yayınevi.

Kaya, E. ve Öner, G. (2017). 100. Yaşındaki sosyal bilgiler dersini sosyalleşme ve toplu öğretim ekseninde yeniden düşünmek. Anadolu Üniversitesi Eğitim Fakültesi Dergisi, 1(2), 1-25.

Kılıç, K. M. ve Güngör-Aytar, F. A. (2017). Erken çocuklukta sosyal becerilere sosyal beceri eğitiminin etkisi, sosyal becerilerle mizaç arasındaki ilişki. Ĕgitim ve Bilim, 42(191), 185-204, https://doi.org/10.15390/EB.2017.7162

Lichtman, M. (2013). Qualitative research in education: A user's guide. Sage Publications.

MEB. (2013a). Okul öncesi eğitimi programı. Ankara: Millı̂ Eğitim Bakanlığı Yayınları.

MEB. (2013b). Okul öncesi eğitim programı - 2013 etkinlik kitabı. Temel Eğitim Genel Müdürlüğü.

MEB. (2015). Millı̂ eğitim bakanlı̆ğ 2015-2019 stratejik planı. Millî Ĕgitim Bakanlı̆̆ı Yayınları.

MEB. (2020). Milli eğitim istatistikleri örgün eğitim 2019-2020. Resmi İstatistik Programı Yayını.

Merriam, S. B. (2013). Nitel araştırma desen ve uygulama için bir rehber. S. Turan (Çev. Ed.). Nobel Yayıncılık.

Miles, M. B. and Huberman, A. M. (1994). An expanded sourcebook: Qualitative data analysis. Sage Puplications.

Mindes, G. (2005). Social studies in today's early childhood curriculum. Young Children, 60(5), 1-8.

NCSS. (2019). Early childhood in the social studies context. https://www.socialstudies.org/positionstatements/early-childhood-social-studiescontext\#: : text=Social\%20studies\%20learning\%20offers\%20many,inclusive\%20and\%20caring \%20de mocratic\%20society.\&text=Teachers\%20serve\%20a\%20direct\%20role,both\%20the\%20systems\%20an d\%20concepts

Öner, G. ve Çengelci Köse, T. (2019). Müze ve tarihi mekânlarda değer ve beceri kazandırmaya yönelik sosyal bilgiler öğretmen adaylarının görüşleri. Turkish History Education Journal, 8(1), 98-128. https://doi.org/10.17497/tuhed.540967

Öner, G. ve Öztürk, M. (2019). Okul dışı öğrenme ve öğretim mekânları olarak bilim merkezleri: Sosyal bilgiler öğretmen adaylarının deneyimi. Eskişehir Osmangazi Üniversitesi Sosyal Bilimler Dergisi, 20(Özel Say1), 1109-1135, https://doi.org/10.17494/ogusbd.

Öngider, N. (2013). Anne-baba ile okul öncesi çocuk arasındaki ilişsi, Psikiyatride Güncel Yaklaşımlar, 5(4), 420440. https://doi.org/10.5455/cap.20130527

Öztürk, M., Giren, S., Yıldırım, E. ve Şimşek, Ü. (2015). Güncellenen okul öncesi eğitim programının coğrafya eğitimi açısından incelenmesi. CBÜ Sosyal Bilimler Dergisi, 13(4), 246-262.

SBDÖP. (2018). Sosyal bilgiler dersi öğretim programı. Millî Eğitim Bakanlığı.

Seefeldt, C., Castle, S. ve Falconer, R. C. (2015). Okul öncesililkokul çocukları için sosyal bilgiler öğretimi, S. Coşkun-Keskin (Çev. Ed.) Nobel Yayıncılık.

Şimşek-Çetin, Ö. ve Akhan, N. E. (2015). Okul öncesi öğretmen adaylarının sosyal bilimler hakkındaki görüşleri. Uluslararası Sosyal Araştırmalar Dergisi, 8(37), 816-828.

Taner-Derman, M. ve Başal, H. A. (2010). Cumhuriyetin ilanından günümüze Türkiye'de okul öncesi eğitim ve ilköğretimde niceliksel ve niteliksel gelişmeler. Uluslararası Sosyal Araştırmalar Dergisi, 3(11), 560569. 
Townsend-Butterworth, D. (2014). What to expect in preschool: social studies. https://www.greatschools.org/gk/articles/your-preschooler-and-social-studies/

Uçuş-Güldalı, Ş. (2017). Sosyal bilgileri okul öncesi dönem çocuklarıyla deneyimlemek: erken çocukluk döneminde sosyal bilgiler eğitiminin önemini gözden geçirme. Ahi Evran Üniversitesi Kırşsehir Ĕgitim Fakültesi Dergisi, 18(3), 1122-1151.

Uçuş-Güldalı, Ş. ve Demirbaş, İ. (2017). Okul öncesi eğitim programı ile ilkokul hayat bilgisi öğretim programının sarmallığının incelenmesi, Mersin Üniversitesi Eğitim Fakültesi Dergisi, 13(3), 1084-1105.

Uzun, M. ve Köse, A. (2017). Okul öncesi eğitimde değerler eğitiminin uygulanmasına yönelik öğretmen görüşleri. Bayburt Eğitim Fakültesi Dergisi, 12(23), 305-338.

Ünlü, M. ve Alkış, S. (2006). Okulöncesi öğretmenliği programlarında coğrafya derslerinin gerekliliğinin irdelenmesi. Marmara Coğrafya Dergisi, 14, 17-28.

Yıldır, N. (1991). Okul öncesi eğitimin önemi ve amacı. YA-PA 7. okulöncesi eğitimi ve yaygınlaştırllması semineri, 25-26-27 Nisan 1991, Eskişehir, Anadolu Üniversitesi. YA-PA Yayınları.

Yıldırım, A. ve Şimşek, H. (2011). Sosyal bilimlerde nitel araştırma yöntemleri. Seçkin Yayıncıllk.

Yiğit, Ö. ve Sezer, T. (2007, Eylül). Aktif vatandaş yetiştirmede okul öncesi dönemin önemi. Sözlü bildiri, XVI. Ulusal Eğitim Bilimleri Kongresi, Tokat. https://www.pegem.net/Akademi/kongrebildiri_detay.aspx?id=101224 


\section{EXTENDED ABSTRACT}

\section{Examination of Teachers' Views on Social Studies Education in Preschool}

Social Studies are taught as compulsory courses in primary and secondary schools in Turkey. However, the individual's need for social studies is so important that it cannot be limited only to certain educational periods. Because the individual's need for knowledge, skills, and values in the context of social studies is a life-long process starting with the need to know himself/herself and make sense of his/her environment. One of the levels where they need social information is the most is preschool education. However, teachers have a great responsibility at this point because the place and importance of social studies in preschool and preschool education programs in our country are not understood sufficiently. For this reason, the research aims to determine the pre-school teachers' views on social studies.

This research aiming to determine the views of preschool teachers on social studies was designed with a qualitative research approach. 39 of the 40 participants in the study group of the research are Women and only 1 is Male.

In the process of obtaining the data of the research, a semi-structured interview form was used as a data collection tool. As a result of expert opinions and pilot applications, a semi-structured interview form consisting of 11 open-ended questions was prepared. The data obtained from the research were analyzed with one of the qualitative data analysis techniques, the descriptive analysis technique. Based on the findings obtained from the study carried out to determine the opinions of preschool teachers on social studies, the following conclusions were reached:

It is determined that a significant part of pre-school teachers' perceptions about social studies constitute History Teaching, Geography Teaching, and Citizenship Knowledge Teaching. This result is an expected and parallel situation with the literature. Because the social studies lesson has content based on history, geography, and citizenship knowledge in the curriculum it has from past to present. It has been revealed that the pre-school teachers in the study group have positive attitudes towards social studies lessons in their past learning experiences, and the reason for this is due to the interest in the content of the lesson. It has been determined that the current perceptions of 40 preschool teachers participating in the study regarding the content of the social studies course mainly consist of History, Geography, and Citizenship, but the participants are not sufficiently aware of other social sciences in social studies.

It has been determined that all preschool teachers participating in the research think that social studies are required in preschool education and therefore, social studies should be included in preschool education. As a result of the research, Geography activities come first among the activities that preschool teachers perform most within the scope of social studies, it has been determined that "climate and weather observation" comes first among the geography activities. As a result of the research, one of the most performed activities for social studies in preschool education is "History Activities" and "Important Turkish Leaders" and "Ataturk Events" which were determined to be at the top of the historical activities.

Another of the activities being carried out within the scope of preschool education is "Out of School Activities". In this context, it was revealed that the teachers carried out "Trip Observation Visits" and "Event and Celebrations Activities". Out-of-school activities can be used for many different purposes in pre-school education. When the opinions of the participants 
are examined, it is seen that a significant part of these activities is oriented towards social studies. As a result of the research, it has been determined that the primary classroom / out-ofschool activities that preschool teachers carry out within the scope of social studies are School Garden, Museums, Cinema, Theater, and Science Center, respectively. It has been determined that Respect and Love are the primary values that teachers who participate in the research attach importance to in pre-school education. As a result of the research, it has been determined that pre-school teachers' perceptions of effective citizens are those who know their rights and responsibilities, are sensitive and beneficial to the environment, produce and serve for their country, fulfill their responsibilities, respect the rights of someone else and love their homeland. Finally, as a result of the research, it has been determined that the teachers are involved in collaboration with the family, organizing out-of-school trips, encouraging students by giving duties and responsibilities, and group games. 